
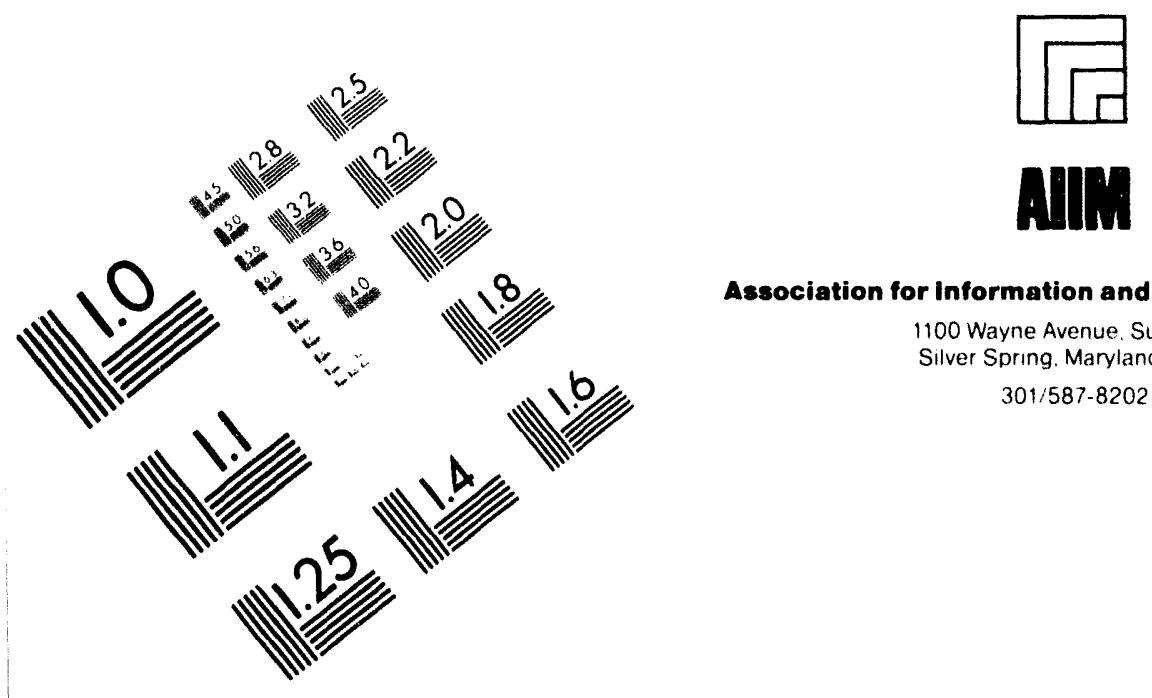

Association for Information and Image Management

1100 Wayne Avenue. Sulte 1100

Silver Spring. Maryland 20910

301/587-8202

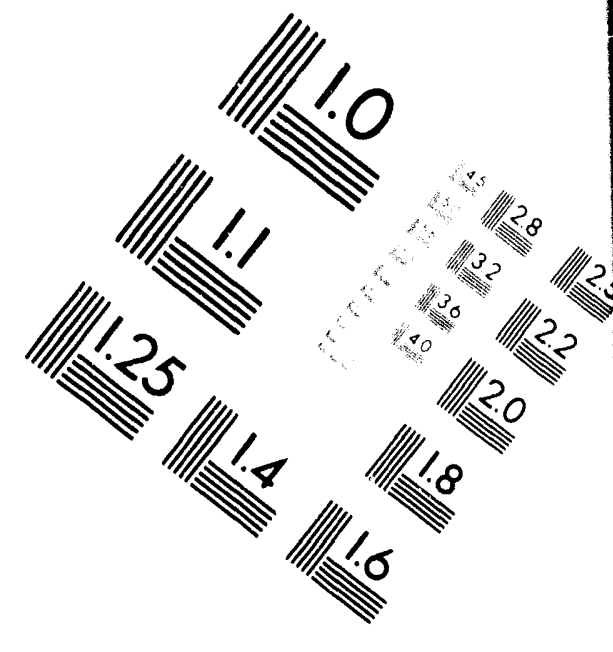

Centimeter

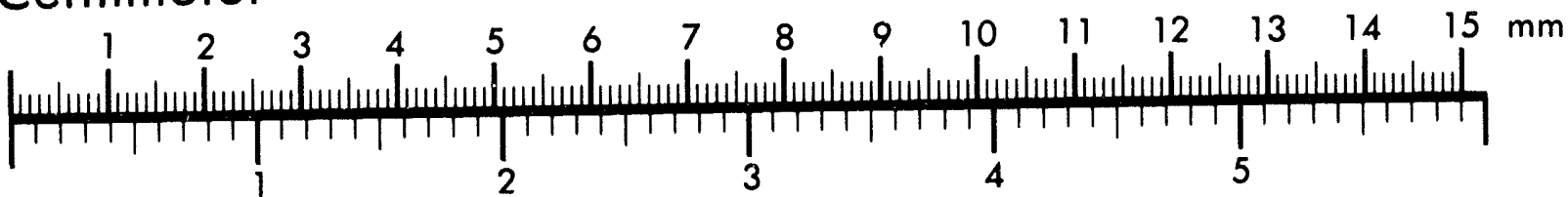

Inches
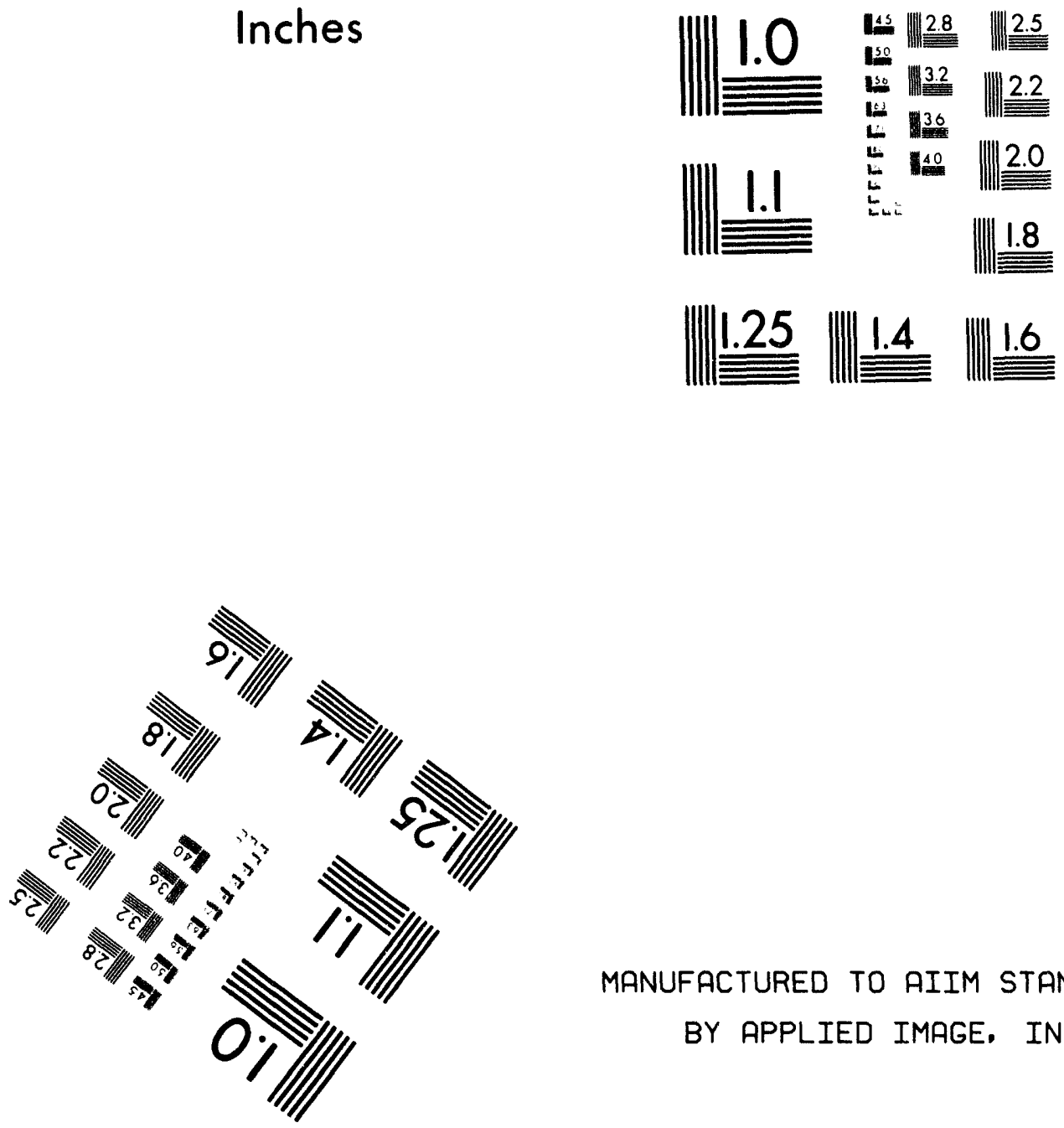

MANUFACTURED TO AIIM STANDARDS

BY APPLIED IMAGE, INC.

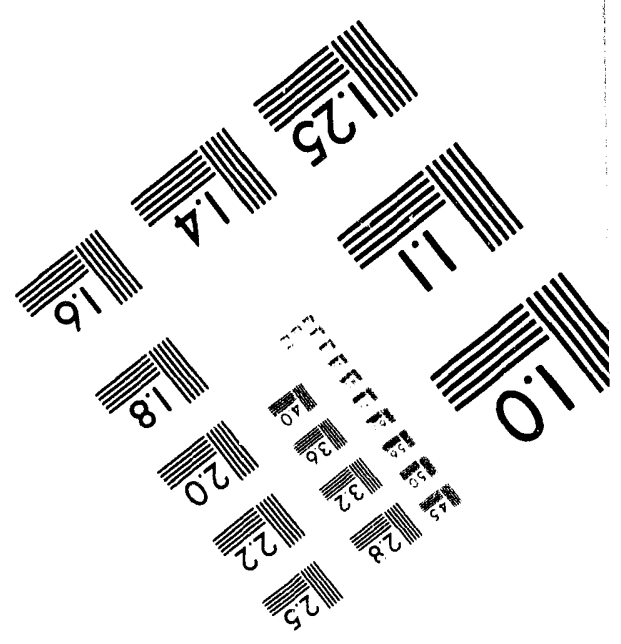



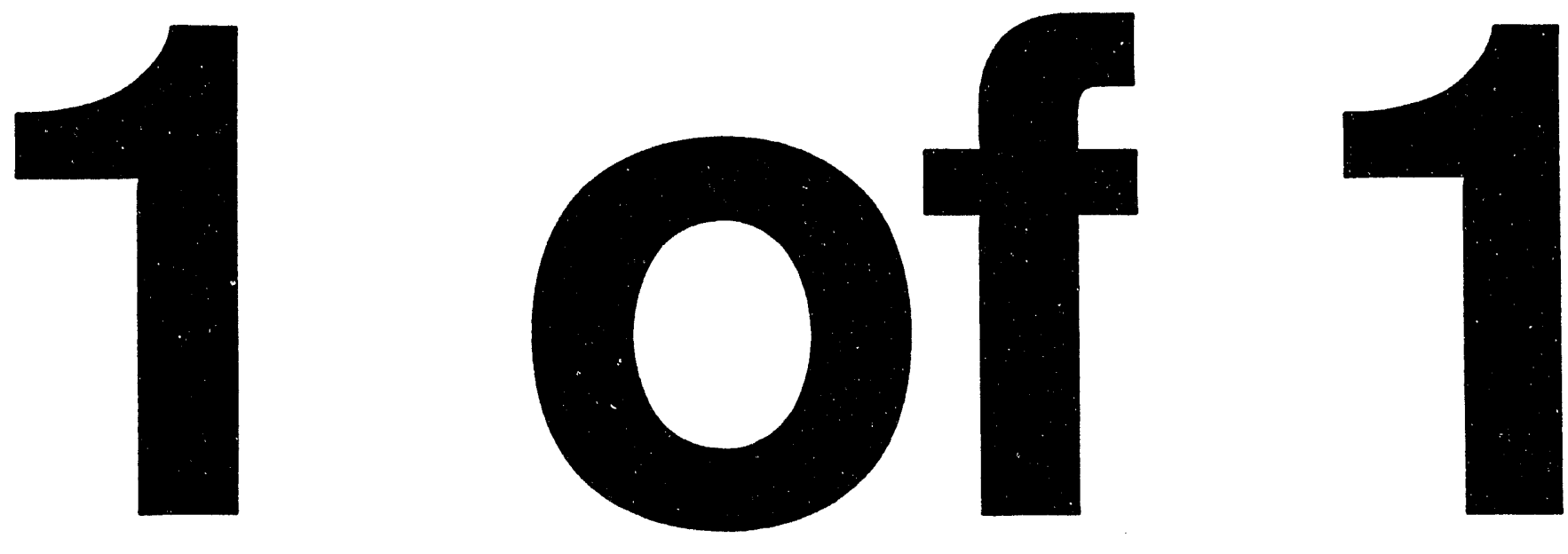
NUREG/CR-6183

ANL-94/3

\section{Peer Review of}

the Three Mile Island Unit 2

Vessel Investigation Project

Metallurgical Examinations

Manuscript Completed: December 1993

Date Published: July 1994

Prepared by

R. W. Bohl*, R. G. Gaydos*, G. F. Vander Voort*, D. R. Diercks

Argonne National Laboratory

9700 South Cass Avenue

Argonne, IL 60439

Prepared for

Division of Engineering

Office of Nuclear Regulatory Research

U.S. Nuclear Regulatory Commission

Washington, DC 20555-0001

*Independent Consultants to Argonne National Laboratory

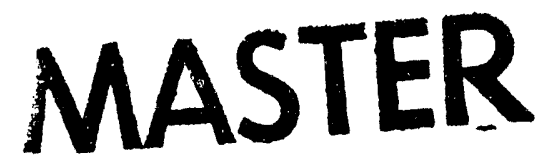

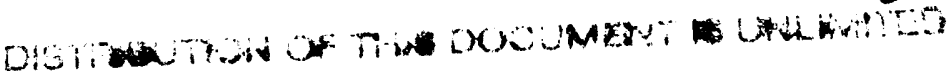


Fifteen samples recovered from the lower head of the Three Mile Island (TMI) Unit 2 nuclear reactor pressure vessel were subjected to detalled metallurgical examinations by the Idaho National Engineering Laboratory (INEL), with supporting work carried out by Argonne National Laboratory (ANL) and several of the European participants. These examinations determined that a portion of the lower head, a socalled elliptical "hot spot" measuring $\approx 0.8 \times 1 \mathrm{~m}$, reached temperatures as high as $1100^{\circ} \mathrm{C}$ during the accident and cooled from these temperatures at $=10-100^{\circ} \mathrm{C} / \mathrm{min}$. The remainder of the lower head was found to have remained below the ferrite-toaustenite transformation temperature of $727^{\circ} \mathrm{C}$ during the accident.

Because of the significance of these results and their importance to the overall analysis of the TMI accident, a panel of three outside peer reviewers, Dr. Robert $\mathbf{W}$. Bohl, Mr. Richard G. Gaydos, and Mr. George F. Vander Voort, was formed to conduct an independent review of the metallurgical analyses. After a thorough review of the previous analyses and examination of photo-micrographs and actual lower head specimens, the panel determined that the conclusions resulting from the INEL study were fundamentally correct. In particular, the panel reaffirmed that four lower head samples attained temperatures as high as $1100^{\circ} \mathrm{C}$, and perhaps as high as 1150 $1200^{\circ} \mathrm{C}$ in one case, during the accident. They concluded that these samples subsequently cooled at a rate of $=50-125^{\circ} \mathrm{C} / \mathrm{min}$ in the temperature range of 600 $400^{\circ} \mathrm{C}$. In good agreement with the original analysis. The reviewers also agreed that the remainder of the lower head samples had not exceeded the ferrite-to-austenite transformation temperature during the accident and suggested several refinements and alternative procedures that could have been employed in the original analysis. 


\section{Contents}

1 Background ................................................................................ 1

2 Detalled Discussion by R. W. Bohl....................................................... 2

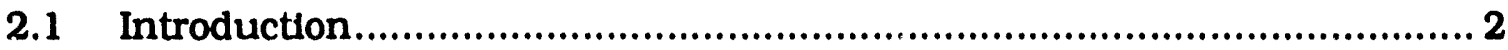

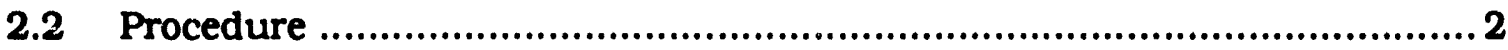

2.3 Comments ......................................................................... 4

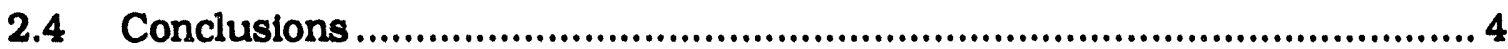

3 Detalled Discussion by R. G. Gaydos ................................................ 5

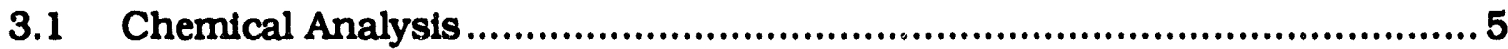

3.2 Check Analysis Sampling ...........................................................6 6

3.3 Nozzle Evaluation ....................................................................6 6

3.4 Repair of Cladding by Welding................................................. 7

3.5 Microstructure and Hardness Evaluation .......................................... 7

4 Detalled Discussion by G. F. Vander Voort ......................................... 14

4.1 Korth's Approach ....................................................................... 14

4.2 Reaustenitization of A533 Gr. B Head Material ................................. 14

4.3 Grain Growth in the Heat-Affected Zone ...................................... 17

4.4 The "Carbon-Diffusion Zone" ........................................................ 18

4.5 Interfacial Dark Etching Zone ............................................. 18

4.6 Carbon-Free/Carbide-Free Equiaxed Grains ................................... 18

4.7 Spheroidization of $\delta$-Ferrite ................................................... 19

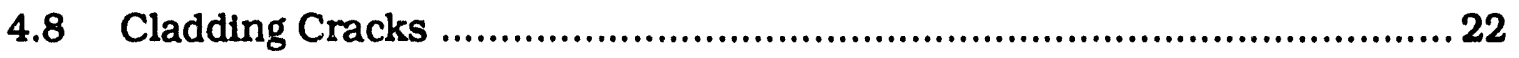

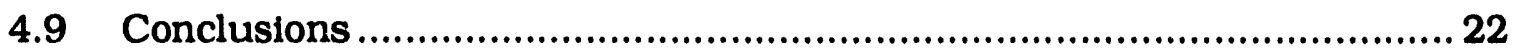




\section{List of Figures}

1. Microstructures at weld clad interface of Samples $\mathrm{K}-13$ and F-10 ................ 8

2. Stainless steel/low-alloy steel interface of Sample F-10 and Sample E-8, lllustrating carbon diffusion band into the stainless steel and the associated cracking

3. Microhardness of Samples F-10 and K-13 as a function of distance from stainless steel/low-alloy steel interface

4. Microstructures at stainless steel/low-alloy steel interface in Samples K-13 and F-10

5. Hardness of martensitic structures as a function of carbon content

6. Continuous-cooling-transformation (CCT) diagram for A533 Grade B steel ..... 15

7. Variation of fraction of $\delta$-ferrite remaining with the logarithm of the aging time at various temperatures .................................................... 20

8. Variation of the shape factor $\mathrm{D} / \mathrm{L}$ with aging time at various temperatures ..... 20

9. Time-temperature-precipitation (TTP) diagram for welded and aged Type 308 stainless steel 


\section{Llst of Tables}

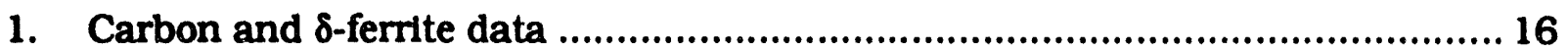




\section{Executlve Summary}

The peer revlew panel (R. W. Bohl, R. Gaydos and G. F. Vander Voort) was requested, under Contract $B 95554$, to review the metallurgical reports dealing with the estimation of the maximum temperature of the lower pressure vessel head of the Three Mile Island (TMI) Unit 2 nuclear reactor as a result of the incident of $28 \mathrm{March}$ 1979. To accomplish this goal, the panel members were supplied with a number of reports prepared by members of the staffs of the Idaho National Engineering Laboratory (INEL) and the Argonne National Laboratory (ANL), plus reports by various cooperative nuclear laboratories in other countries. Panel members also visited ANL on 2-3 June 1993 to discuss the reports, view original photo-micrographs, and examine the microstructures of specimens taken from the TMI-2 lower head as well as that of control specimens from an unused reactor head subjected to various thermal exposures. The panel also met with the Nuclear Regulatory Commission (NRC) in Rockville, MD on 26 August 1993 to present its findings.

Each panel member prepared a report of his findings. These reports are presented here. Each member's review of the work was based on his own personal experiences and background. While the nature of their findings and conclusions vary somewhat on minor detalls, the panel members are in agreement as to the overall conclusions. These conclusions are listed below:

- There was no evidence of melting or incipient melting in any lower head boat specimen.

- Only four specimens (E-6, E-8, F-10 and G-8), all from the same general region of the lower head, reached temperatures in excess of the critical temperatures for ASTM A533 Gr. B which were in the range of 715-720 and $830-850^{\circ} \mathrm{C}$, respectively, for the $\mathrm{Ac}_{1}$ and $\mathrm{Ac}_{3}$, the lower and upper critical temperatures. Heating above these temperatures produres a fully austenitic $(\gamma)$ microstructure that will transform upon cooling back to ambient temperature.

- For Specimens E-6, E-8, F-10 and G-8, temperatures remained $>\mathrm{Ac}_{3}$, i.e., $>\sim 850^{\circ} \mathrm{C}$, to the full depth of the boat specimens, $=40-67 \mathrm{~mm}$, depending upon the specimen.

- The conclusions of G. E. Korth about the maximum temperature attained in each of these four specimens (1.e., G-8 and F-10 reached $\approx 1040-1060^{\circ} \mathrm{C}$ for 30 $\mathrm{min}$ and E-6 and E-8 reached $\approx 1075-1100^{\circ} \mathrm{C}$ for $30 \mathrm{~min}$ ) appear to be reasonably accurate, probably within $\pm 50^{\circ} \mathrm{C}$.

- It is possible that Specimen E-8 may have attained a temperature as high as $1150-1200^{\circ} \mathrm{C}$, but certainly no higher. 
- Definition of the maximum temperatures experienced by specimens E-6 and G-8 is less precise than that for E-8 and F-10 because of the surface metal removed in order to decontaminate E-6 and G-8.

- For the four specimens that were heated enough to form austenite (E-6, E-8, F-10, and G-8), the cooling rate through the $\gamma$ transformation regicn was fast enough to form a relatively hard bainitic microstructure. This structure forms at cooling rates between $=50$ and $125^{\circ} \mathrm{C} / \mathrm{min}$ in the temperature range of 600 $400^{\circ} \mathrm{C}$.

- Gross tears were observed in the cladding from the E-6 and G-8 locations, 1.e., within the region that experienced the highest temperatures. In this region, the temperature was high enough to partially dissolve and spherofdize the delta ( $\delta$ ) ferrite in the T308 stainless steel cladding. The cracks appear to be hot tears, which form as a consequence of the inability of the nearly fully austenitic structure to accommodate shrinkage stresses upon cooling to ambient temperature.

- The remaining eleven specimens attained temperatures, in the A533 Gr. B head, of $\angle A c_{1}$, 1.e., $<715^{\circ} \mathrm{C}$.

Robert W. Bohl

Richard Gaydos

George F. Vander Voort 


\section{Background}

The Three Mile Island (TMI) Vessel Investigation Project is an international program sponsored jointly by the U.S. Nuclear Regulatory Commission (NRC) and the Organisation for Economic Co-operation and Development/Nuclear Energy Agency (OECD/NEA). Participants in this program include the U.S., Japan, Belgium, Germany, Finland, France. Italy, Spain, Sweden, Switzerland, and the United Kingdom. 1

During the first phase of this project, 15 samples were removed from the lower head of the TMI Unit 2 nuclear reactor. These prism-shaped samples, each extending approximately half-way through the lower head thickness, were subjected to initial examinations at Argonne National Laboratory (ANL) and then decontaminated and sectioned into metallographic and mechanical test specimens. Detailed examinations of the metallographic specimens were performed at the Idaho National Engineering Laboratory (INEL), with supporting work carried out by ANL and several of the European participants. ${ }^{2-4}$

These metallographic examinations revealed that a portion of the lower head, a so-called elliptical "hot spot" that measured $\approx 0.8 \times 1 \mathrm{~m}$, reached temperatures as high as $1100^{\circ} \mathrm{C}$ during the accident and cooled from these temperatures at $\approx 10$ $100^{\circ} \mathrm{C} / \mathrm{min}$. These rather unexpected results are of great importance to the overall analysis of the TMI accident and, in particular, to the calculation of the margin-tofailure for the lower head. Accordingly, the NRC directed that ANL secure the services of three outside peer reviewers to conduct an independent review and critique of these examinations and the conclusions reached. This review has been completed and the findings of the reviewers, Dr. Robert W. Bohl, iMr. Richard G. Gaydos, and Mr. George F. Vander Voort, are summarized here. 


\section{Detalled Dlscussion by R. W. Bohl}

\subsection{Introduction}

The Metallurgy Peer Review Panel was charged with evaluating the results reported by various laboratories which examined specimens taken from the lower head of the TMI-2 reactor vessel. These investigations were designed to determine temperatures reached by the vessel during the core meltdown in order to assess the severity of the threat to the vessel integrity caused by the deposition of core debris on the lower head.

\subsection{Procedure}

The panel was provided with reports from the varlous cooperating laboratorles, and met at ANL on June 2-3, 1993 to discuss the reports, view original data, and examine metallographic samples taken from the vessel, as well as those from the Midland reactor (archival material), which had been subjected to a range of thermal cycles.

Conclusions regarding the thermal history of the vessel as a result of the accident were based on modifications to the properties (particularly hardness) and the microstructure of the as-fabricated vessel by the thermal excursion experienced.

The vessel was fabricated from $136 \mathrm{~mm}$-thick A533B ferritic steel plate, quenched and tempered at $-660^{\circ} \mathrm{C}$, upon which $5 \mathrm{~mm}$ of $308 \mathrm{~L}$ stainless steel was weld-cladded to the inside surface. After welding, the vessel was stress-relief annealed $50 \mathrm{~h}$ at $=600^{\circ} \mathrm{C}$. There is some discrepancy in the carbon content reported for the samples. A533B specifications call for $0.25 \%$ carbon maximum. Analyses reported range from $0.22 \%$ (ladle analysis) to $0.28 \%$. This range is beyond the tolerance required for chemical analysis and may be rationalized on the basis of the method of analysis (not reported) or the sampling technique used to accommodate the chemically banded plate. Hardness values are sensitive to carbon content, and might affect the hardness levels measured, but not affect the change in hardness observed in the gradient. The variation in carbon composition would not materially affect the temperatures at which microstructural changes took place.

The fabrication of the vessel produced a microstructural gradient with the following features:

1. Columnar weld metal containing about $5 \% \delta$-ferrite in an interdendritic network.

2. A "dark band," at the WM-BM interface, which was very hard and formed when the highly alloyed stainless steel was mixed with the carbon-bearing steel plate. The nature of this band was not determined, nor was its identification necessary to establish the temperature gradients attained. 
3. A heat-affected base metal zone where the heat of welding raised the base metal into the austenite range, producing a large austenite grain size to a depth of about $10 \mathrm{~mm}$ below the junction.

4. The base metal heated to temperatures below the lower critical transformation temperature, and consisting of the original tempered bainite structure, 1.e., small precipitated carbides.

As molten core material deposited on the lower head, the temperature increased and modifled the as-fabricated microstructure. The following changes (in order of occurrence with decreasing temperature) could occur and identify the temperatures reached during the meltdown:

1. Remelting of the weld clad: $1400^{\circ} \mathrm{C}$. Since no melting of the clad was observed, this temperature was not reached.

2. Agglomeration and partial solution of $\delta$-ferrite in the weld metal: 1100 $1150^{\circ} \mathrm{C}$.

3. Grain growth of austenite in the base metal: $1050^{\circ} \mathrm{C}$.

4. Solution of the dark band: $850-900^{\circ} \mathrm{C}$.

5. Transformation of the base metal to fine-grained austenite: $850^{\circ} \mathrm{C}$

6. Decomposition of $\delta$-ferrite to sigma in the weld metal: $700^{\circ} \mathrm{C}$. Since the weld metal was clearly heated above this temperature range in the critical hot zone, this change is of little significance.

7. Initial formation of austenite in the base metal: $727^{\circ} \mathrm{C}$.

8. Coalescence of the tempered bainitic carbides in the base metal heated below the lower critical temperature. Since the as-fabricated vessel was stress relieved $50 \mathrm{~h}$ at $600^{\circ} \mathrm{C}$, any additional coarsening caused by brief heating between this temperature and $727^{\circ} \mathrm{C}$ would likely be imperceptible.

The microhardness surveys provided valuable insight into the effect of the thermal excursion on the steel vessel. As the ferritic steel was heated over the critical temperature, the effects of the fabrication history, particularly the stress-relief anneal, were eliminated and the structure and hardness were controlled by the attained austenite grain size and the cooling rate. Abrupt changes in both structure and hardness were noted in the samples taken from the "hot zone," 1.e., E-6, E-8, F-10, and G-8. Since no other region of the lower head reached these temperatures, attention was concentrated on samples taken from this sensitive region.

The avallability and use of the Midland archive vessel to simulate various timetemperature-cooling rate histories was a very valuable aspect of the metallurgy 
analysis. The validity of conclusions based on observations of the TMI-2 vessel samples was strongly confirmed by the ability to simulate these features with the Midland vessel steel.

\subsection{Comments}

If one were to design this study with the benefit of hindsight, there are some features which may have been modified: metallographic studies might have included the use of selective etchants to better reveal the austenite grain size in the heataffected regions; more use of quantitative metallography might have shed more light on regions of grain-size gradients; exclusive use of microhardness testing could better define hardness gradients; and taking some samples from the outer surface of the lower head (perhaps this was not feasible) could better define temperatures throughout the vessel wall. Temperature gradients through the $50-\mathrm{mm}$-deep samples suggest that, even in the hottest zone, the outside wall did not exceed $700^{\circ} \mathrm{C}$; these gradients appear to be $\approx 3^{\circ} \mathrm{C} / \mathrm{mm}$. Members of the panel agree, however, that such refinements would not affect the final conclusions of the Metallurgy Program to any significant degree.

\subsection{Conclusions}

There are a great number of uncertainties necessary to accurately model the threat to the integrity of the vessel during this accident. Fortunately microstructural features are based on material properties that are not subject to assumptions; e.g., the steel either exceeded the critical temperature or it did not, as revealed by the microstructure. In my opinion, the Metallurgy Program was well-conceived and carried out, and I concur with the conclusions reached. The close agreement among the laboratories that independently carried out parallel studies constitutes strong support for the interpretations reported. While details of heat transfer, molten core deposition rates, cooling scenarios, etc., may be obscure, the results of these studies are sound and valid. 


\section{Detalled Discussion by R. G. Gaydos}

The objective of the peer consultants was to review the method of examination of the postaccident A533B pressure vessel and the conclusions formed. The objectives of the INEL and ANL Laboratories were to determine, by metallurgical methods, the peak thermal temperatures reached to assess, to the extent possible, the margin to fallure.

Numerous reports, which encompassed findings to develop scenarios of the accident, were studied. Nozzle examinations, mechanical tests, and microstructural examinations of the lower head samples were conducted.

The metallurgical sampling, sample preparation, photomicrographs, and lastly, but most important, microscopic examinations of numerous samples taken from the lower head and Midland archive material were compared. Heat-treating cycles were performed with the aid of continuous-cooling curves to evaluate temperatures reached.

The studies were helpful in developing a scenario of events in the lover head during the accident. The delineation of a "hot spot" evolved through studies of microstructural changes from the temperature attained (approaching $1100^{\circ} \mathrm{C}$ ) on or near the cladded surface. Similarly, the periphery of the "hot spot" was ascertained by microstructural changes that resulted from exceeding or approaching the lower critical temperature in the $\mathrm{A} 533 \mathrm{Gr}$. B steel $\left(727^{\circ} \mathrm{C}\right)$.

Exact evaluation of phases present was qualitative at best. The nozzles and base metal indicated significant insulating effects by some debris and core material. The extreme temperatures appeared to have occurred some distance above the cladded base. The tumult resulting from core material, fuel elements, and water provided a highly variable system. Detailed quantification may have improved the outline of the "hot spot;" however, since microstructural changes involve time and temperature, exactness in such a highly varlable system is nebulous.

This reviewer is in basic agreement with the findings and conclusions of $G, E$. Korth of INEL and D. R. Diercks and L. A. Neimark of ANL. Lastly, in the category of lessons learned, some differences shall be discussed.

\subsection{Chemical Analysis}

As will be discussed under microstructure, carbon analysis is important to better understand the diffusion occurring during cladding.

Ladle analysis is the term applied to the chemical analysis representative of the heat. It is common practice to obtain three or more molten samples during teeming operations from the first, middle, and last portions of the heat. These samples are used to represent the chemical analysis of the entire heat. 


\subsection{Chock Analysis Sampling}

Each heat or lot must be considered separately. Because of segregation, the location at which samples are taken is important. Simply put, the following, although abbrevlated, may be considered standard practice:

1. For thicknesses $>2$ in. $(5.08 \mathrm{~cm})$, samples are taken by drilling the edge of the plate at a point midway between the rolled surface and the midthickness.

2. Sample drillings are obtained with a $1 / 2-\mathrm{ln} .(1.27-\mathrm{cm})$ drill.

3. Samples must be uniform and well mixed. Those to pass an ASTM No. 10 $(2000-\mu \mathrm{m})$ sleve or too fine to remain on an ASTM No. $30(590-\mu \mathrm{m})$ sieve are not recommended.

4. Samples can be compacted for spectrographic analysis.

5. Carbon analysis is always determined by wet chemistry. Spectrographic checks for carbon are not reliable.

6. For carbon, an allowance of $0.02 \%$ is allowable for plate containing up to 0.30 wt. \% C. A carbon check greater than $0.24 \%$ would be considered rejectable for plate reported as $0.22 \% \mathrm{C}$.

Since carbon, silicon, and especially phosphorus are subject to segregation, their influence on diffusion during cladding is important.

Three samples of TMI-2 materials were checked at $0.25 \%$ C. Sample 1 was reported at $0.28 \% \mathrm{C}$. The vendor reported a heat analysis of $0.22 \% \mathrm{C}$ and $0.17 \% \mathrm{Si}$. Four samples of TMI-2 material were checked for $\mathrm{SI}$ at $0.11,0.16,0.20$, and 0.18 respectively. For up to a $0.30 \% \mathrm{C}$ heat, a $0.02 \% \mathrm{Si}$ variation is allowed.

It appears that the method of sample preparation or method of testing for chemical analysis is reflecting the banded (segregated) microstructure in the plate. The $P$ content was $0.008 \%$ in all four samples vs. the vendor's heat analysis of $0.014 \%$.

The vendor's and check analysis for $\mathrm{P}$ and $\mathrm{S}$ meet "firebox quality." This quality is intended for application in pressure vessels when exposed to fire or radiant heat where thermal and mechanical stresses may be encountered.

\subsection{Nozzle Evaluation}

An area of concern to this reviewer was related to the microstructural aspects where the nozzles were welded to the base. After some discussion, it was related that an error in nozzle sizing during construction resulted in removal of the nozzles and 
repair welding. Since regions of investigation were associated with the "hot spot" where nozzles were severely attacked, there was the danger of confusing previous repair welding effects and changes related to the accident. In at least one instance, the writer and D. Diercks agreed that one exarnined nozzle fell into this category.

Overall, the writer agreed with $\mathrm{D}$. Diercks' concluding scenario regarding the nozzles.

\subsection{Repair of Cladding by Wolding}

The writer emphasized that both AIME and ASTM have produced documents on quality control. In particular. ASTM A647 is a standard specification of special requirements for steel plates for nuclear and other special applications. The spectfication relates to such items as repair welds, repair of cladding by welding, and nondestructive testing (NDT) of repair welds, etc. The manufacturer would be responsible for any documentation regarding cladding, repair weling, NDT, etc.

It was roted that at least one OECD membera observed holes at the clad/base metal interface. Flaws of this magnitude should be detectable by NDT.

\subsection{Microstructure and Hardness Evaluation}

A number of photomicrographs display a "dark feathery" structure in the stainless clad/base metal fusion zone. The archive material and areas of the TMI-2 samples that were not heat affected display the dark structure of varying thickness. The variations in this dark etching carbide precipitate encountered by OECD members, ANL, and INEL investigators are typical of hand applied clad.

All investigators noted that the heat affected samples E-6, G-8, E-8, and F-10 exhibited dissolution of the dark feathery structure. The structure persists in regions not affected. Microstructures comparing such structures (F-10 and K-13) are appended as Fig. 1. After repolishing and re-etching by the review team, the structure was found to have characteristics of bainite.

Since the dark structure is the result of carbon diffusion during cladding, the exact identification is not critical in evaluating the extent and magnitude of the heat affected zone (HAZ). Similarly, several laboratorles measured the amount of delta ferrite to vary from 4 to 5\%. Again, quantification is not critical since it too would be expected to vary.

More importantly, the spheroidization of the $\delta$-ferrite phase could be utilized to establish time and temperature relationships in the HAZ.

aW. Vandermeulen and W. Hendrix, Examination Report of the Samples of the TMI-2 RPV Received by SCK/CEN (Belgium), SCK/CEN, Mol (March 1992). 


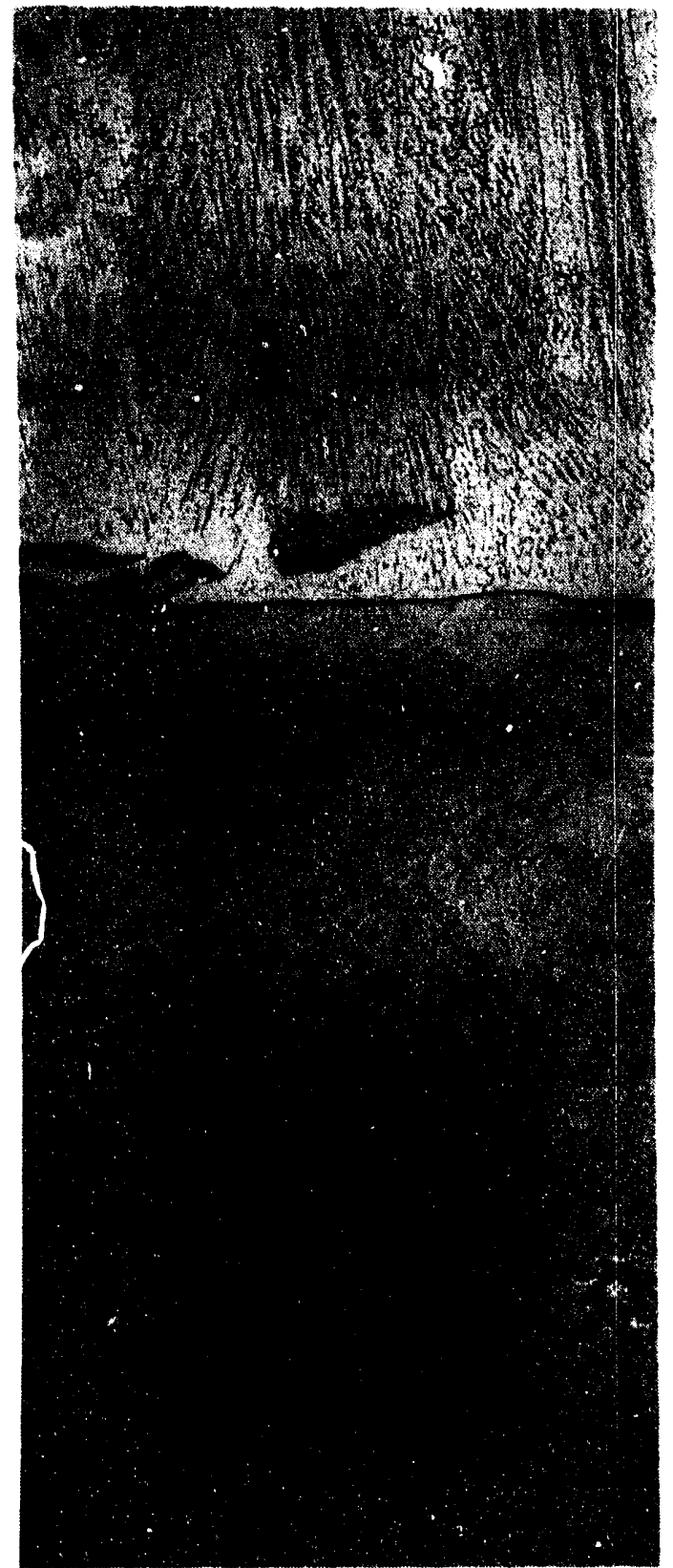

K-13, no damage during accident

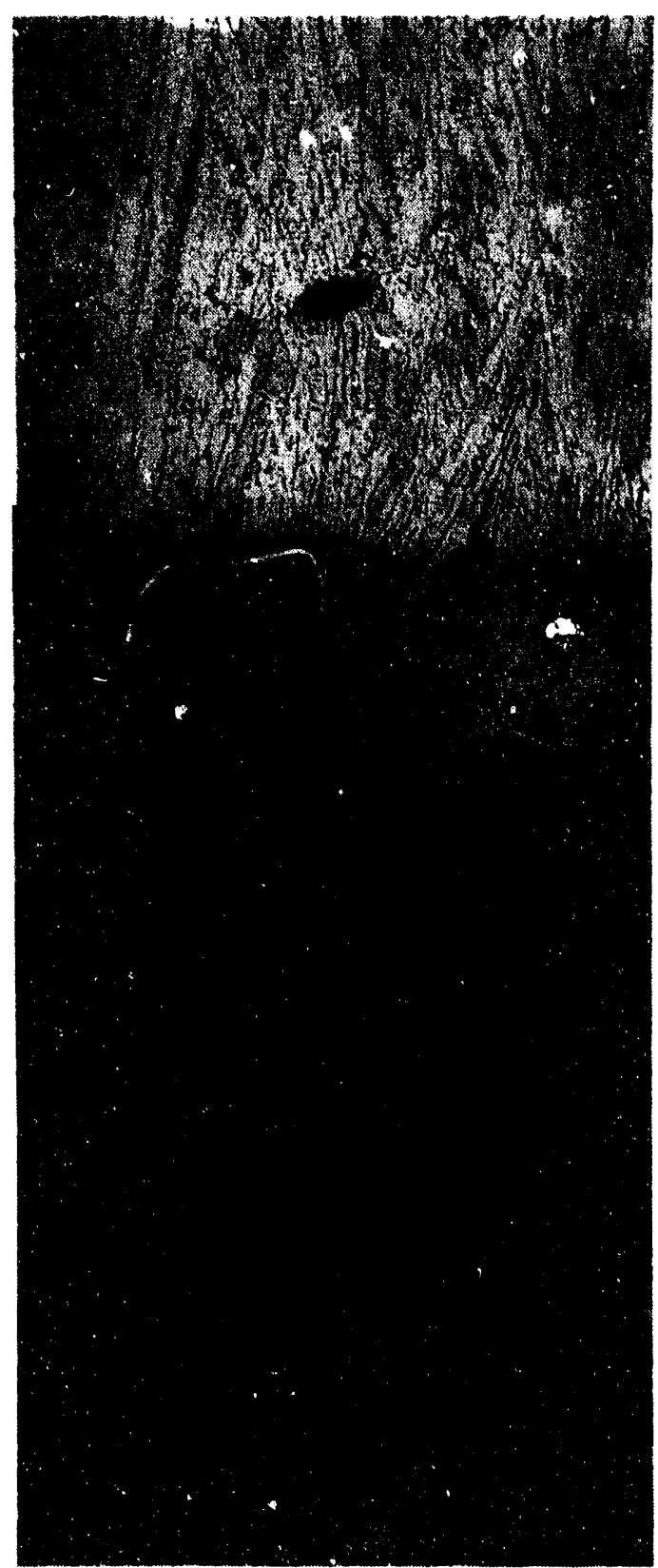

F-10, known thermal damage in accident

Fig. 1. Microstructures at weld clad interface of Samples K-13 (left) and F-10 (right). 


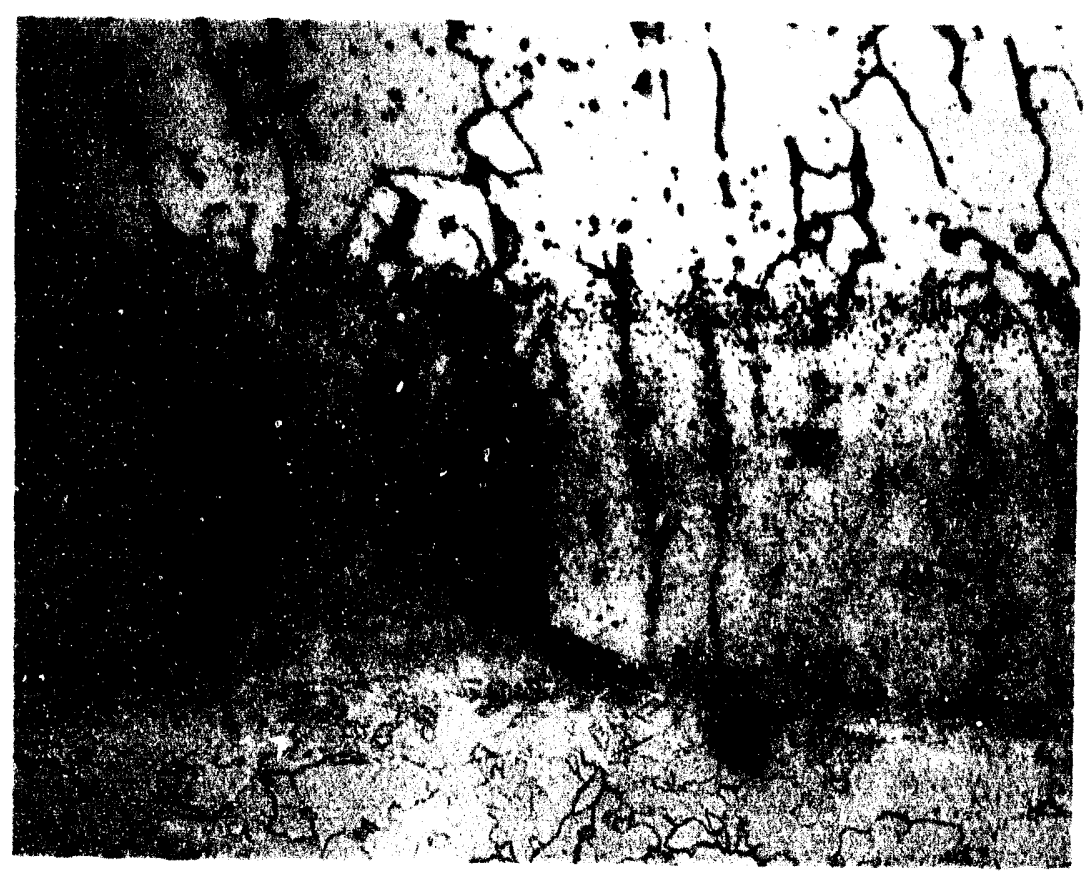

(a)

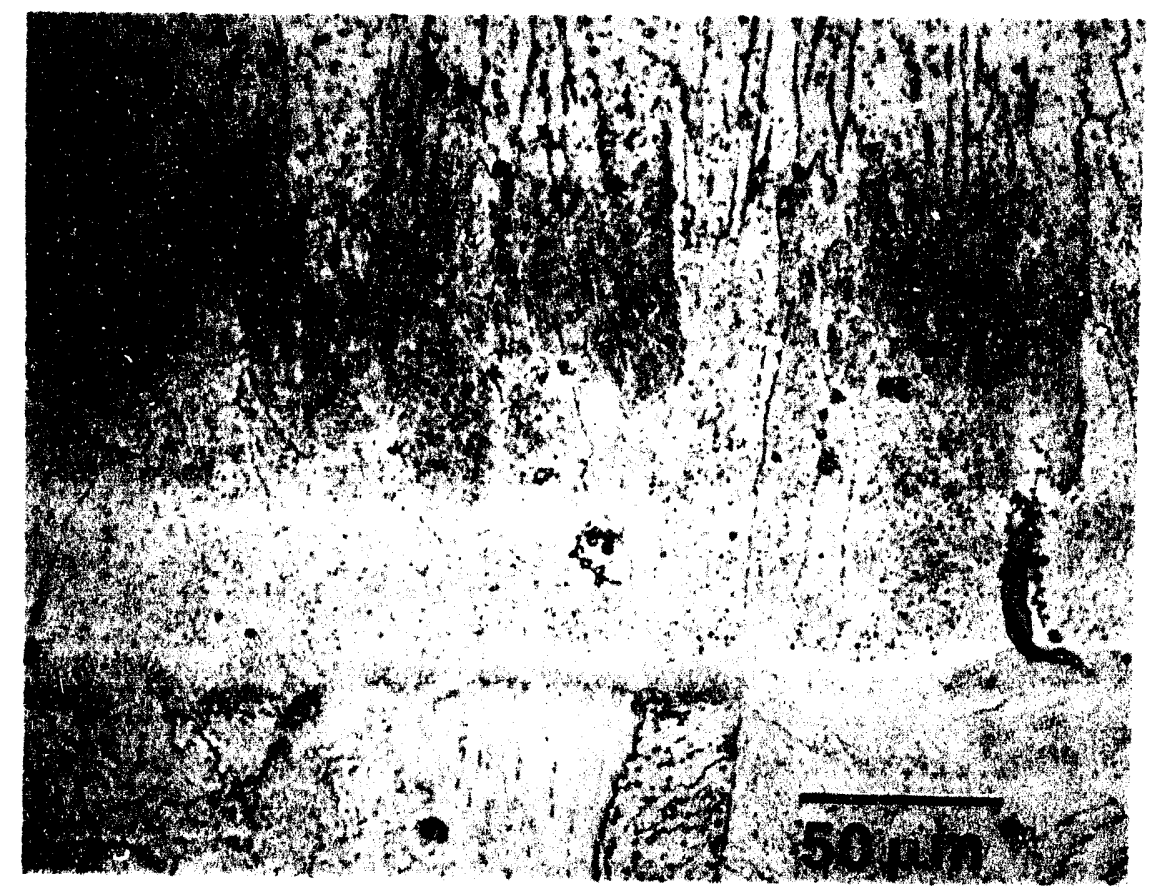

(b)

Fig. 2. Stainless steel/low-alloy steel interface of (a) Sample F-10 (m3) and (b) Sample E-8 (m3), illustrating carbon diffusion band into the stainless steel and the associated cracking. 


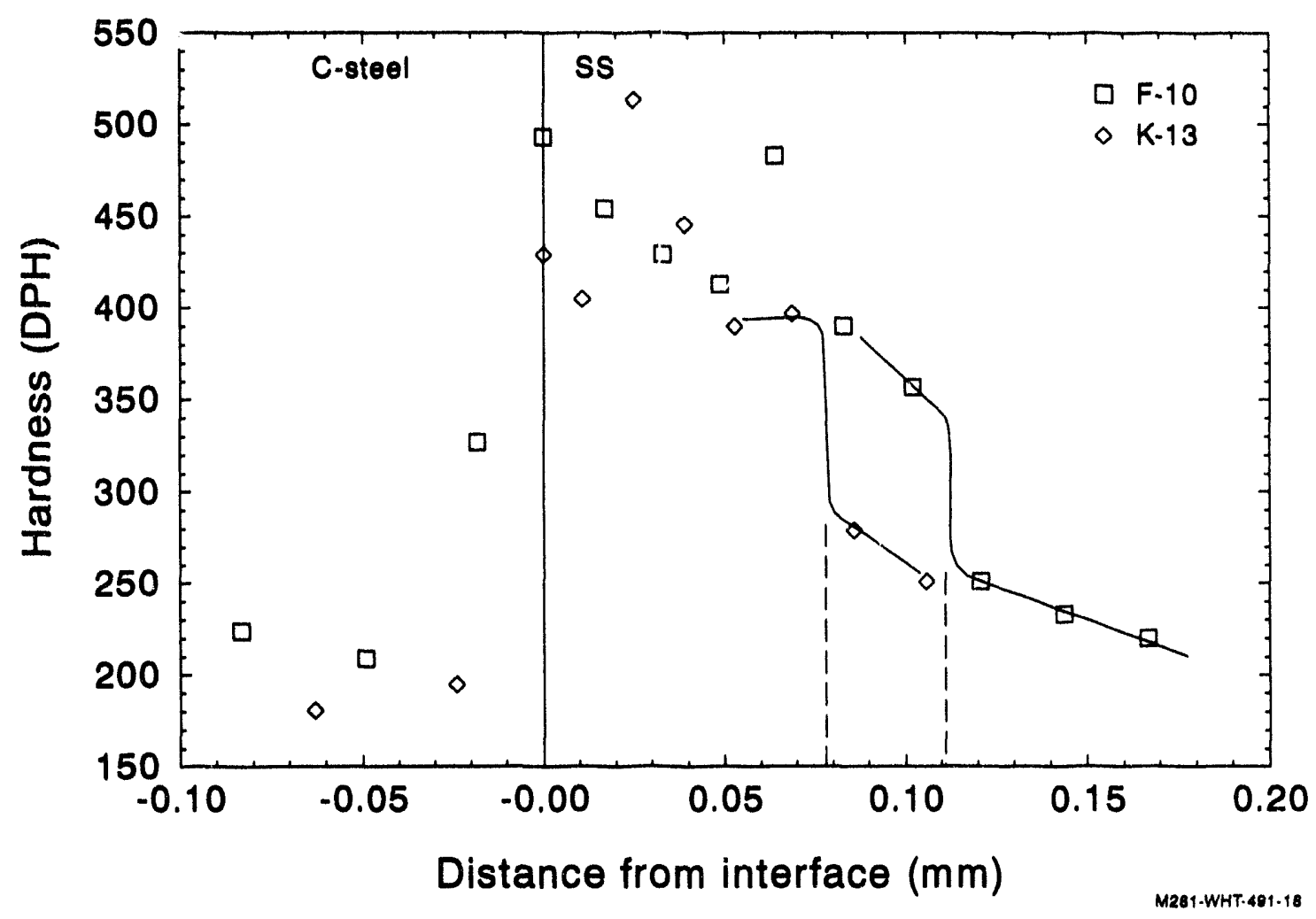

Fig. 3. Microhardness of Samples F-10 and K-13 as a function of distance from stainless steel/low-alloy steel interface (from Ref. 2).

The "hot spot" was also noted by most investigators. Generally the graincoarsening temperature for fine grain, aluminum-killed low carbon, alloy steel will range from $=1800^{\circ} \mathrm{F}\left(982^{\circ} \mathrm{C}\right)$ to $2000^{\circ} \mathrm{F}\left(1093^{\circ} \mathrm{C}\right)$. A value of $1100^{\circ} \mathrm{C}$ cited by $\mathrm{ANL}$ and INEL is in reasonable agreement. Grain growth, being time- and temperaturedependent, would be expected to vary in a variable system.

Also, due to the heterogeneity (segregation) common to low-carbon steel plate, the variability of chemistry would be expected to result in additional variations among the investigators.

Cracks were observed which were restricted essentially to the diffusion zone at the clad/base metal interface, as shown in Fig. 2 (taken from Ref. 2). Also appended are a hardness survey of Sample F-10 from the "hot spot" and of unaffected Sample K-13 (Fig. 3), and additional photomicrographs of Samples F-10 and K-13 (Fig. 4).

The hardness surveys clearly display an extension of the hardened zone from heat effects and carbon diffusion resulting from the accident. 


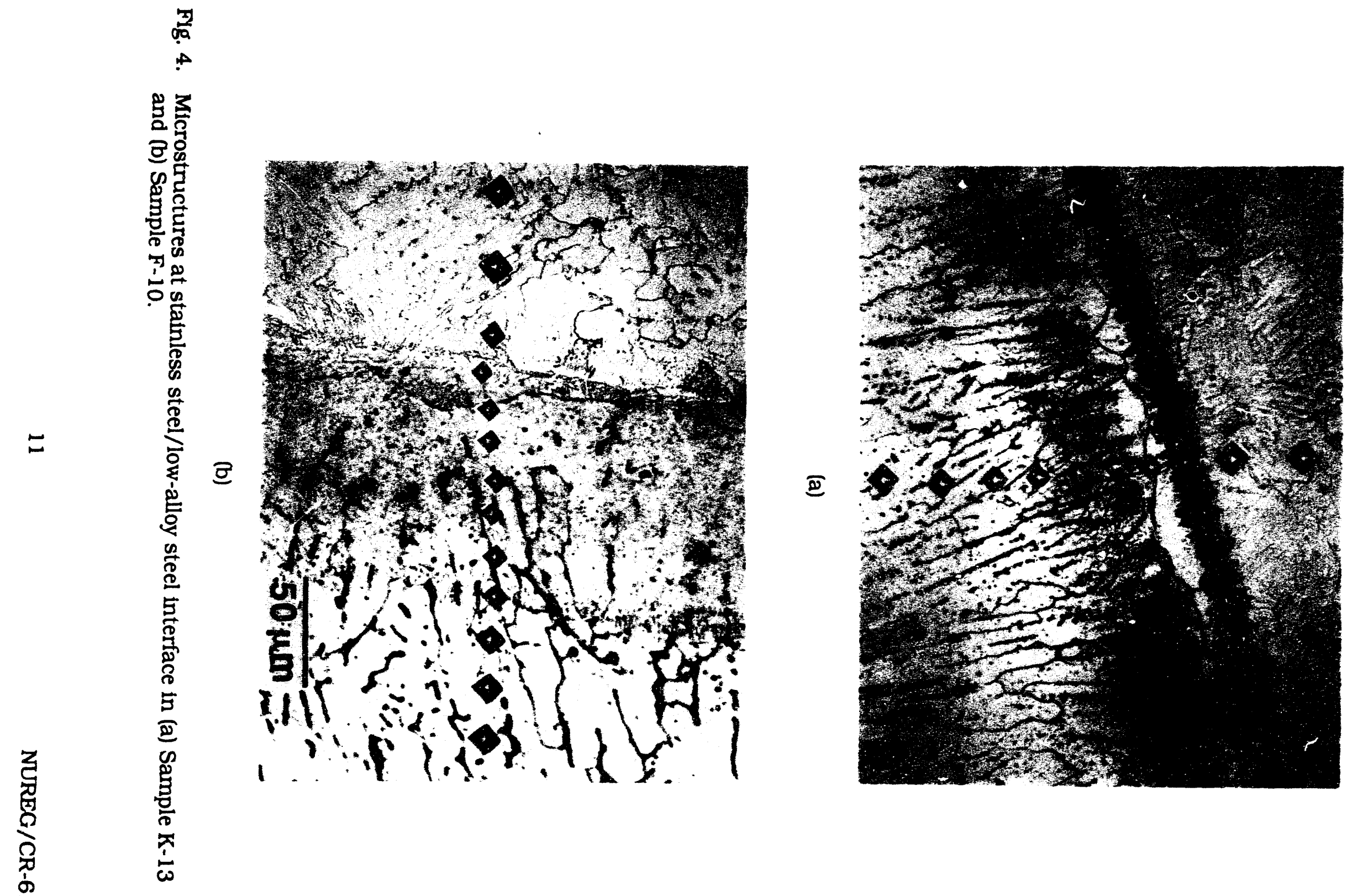




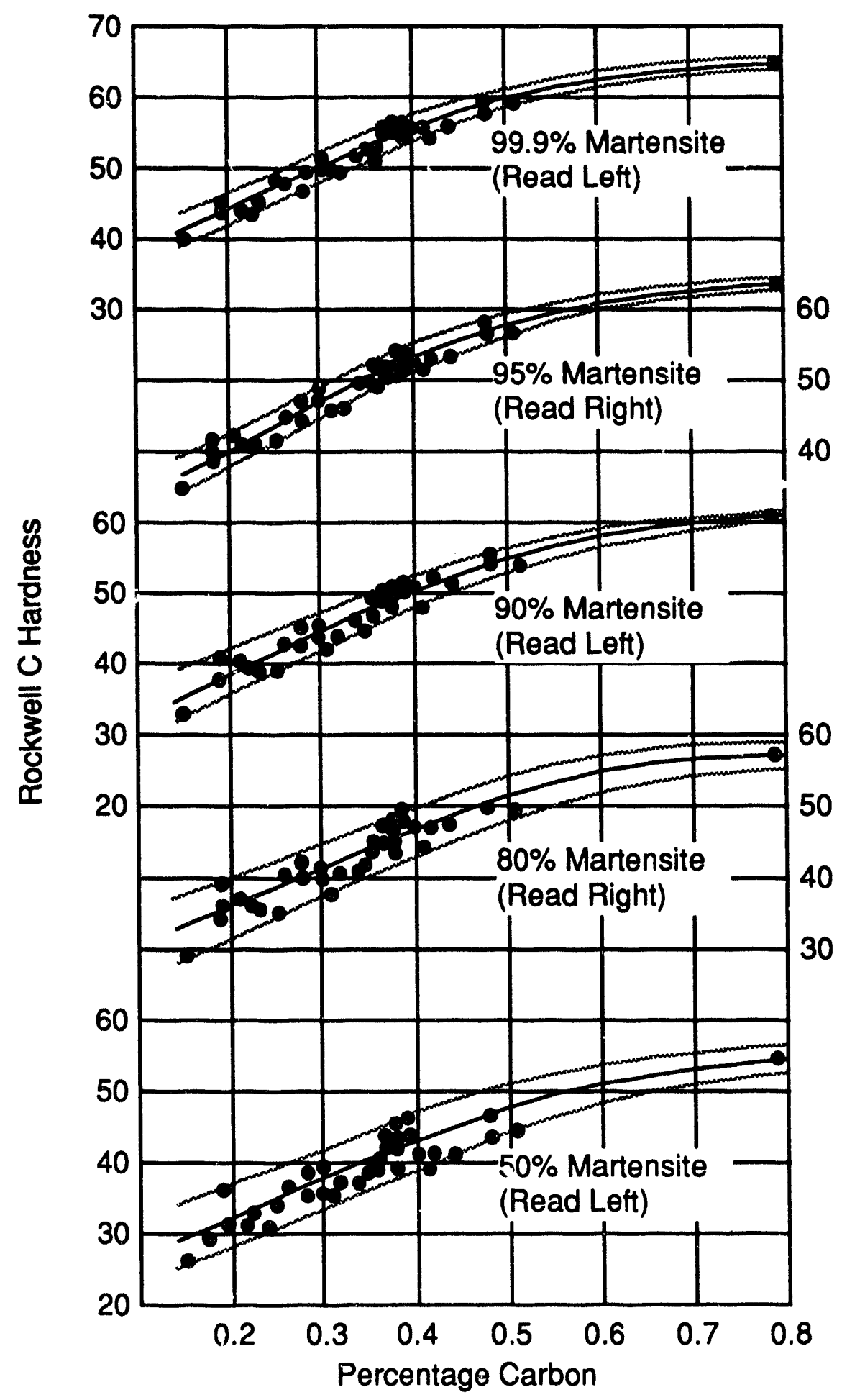

Fig. 5. Hardness of martensitic structures as a function of carbon content (adapted from Ref. 5, used by permission of LTV Steel Corp.). 
Microcracks restricted to the hardened zone indicate cooling at a rate sufficient to cause hardening (500 DPH; $\approx \mathrm{Rc} 50$ ). Microcracks restricted to the hardened region indicate contraction resulting from tempering of the martensitic zone.

A relationship exists between hardness and the carbon content, as shown in Fig. 5. 5 Also a relationship exists between the rate temperability of martensite and carbon content; lower carbon martensites are less stable at elevated temperatures.

The carbon content of any given carbon steel is generally lower near the hotrolled surface, requiring time for diffusion (refer to chemical check analysis). Lastly, increasing the carbon and coarsening the austenitic grain size would shift the $\mathbf{M}_{\mathbf{s}}$ of the cooling curves down in temperature and increase the time. Hence, a lower cooling rate would enable the formation of nuartensite followed by tempering sufficient to cause microcracking.

Considering the mass involved, it is difficult for this reviewer to rationalize coolirig rates of $\geq 50^{\circ} \mathrm{C} / \mathrm{min}$. Certainly turbulence would enhance cooling, and in the presence of water at temperatures in excess of $500^{\circ} \mathrm{C}\left(932^{\circ} \mathrm{F}\right)$, turbulence can be envisioned. The $\mathbf{M}_{\mathbf{s}}$ of the carbon-enriched clad high in nickel could be depressed to allow the mass of the plate to be effective in providing a cooling rate, similar to welding, to form martensite. Residual heat flow would temper the martensite to cause localized microcracking.

In summary, the findings of G. E. Korth, D. R. Diercks, and L. A. Neimark appear to be reasonable. Both INEL and ANL personnel are to be commended for designing an approach to investigating the failure in achieving their objective of evaluating the margin to failure.

A constructive critique would be that consultants could have contributed additional expertise to refine the findings at an earlier date. It is realized that budgetary constraints are in effect; however, national laboratories should be allowed to acquire state-of-art capabilities. However, this reviewer does not feel that additional investigation or refinement is warranted. In view of the degree of core loss, the vessel containment appeared to have withstood the accident to a greater degree than may have been anticipated. 


\section{Detalled Dlscussion by G. F. Vander Voort}

The panel (R. W. Bohl, R. Gaydos, and G. F. Vander Voort) was requested to review the metallographic studies conducted to determine the maximum temperature reached in the lower pressure vessel head of TMI-2 as a result of the incident of 28 March 1979. The review was focused on the report prepared by G.E. Korth 2 but also included other relevant studies conducted at ANL and by nuclear laboratories in a number of other countries.

\subsection{Korth's Approach}

The conclusions as to the peak lower-head temperature were based upon qualitative comparisons of the microstructure of specimens from the lower head to that of specimens from a reactor never placed in service that were subjected to varlous reheating temperatures and times. Estimates of the temperature and time that each TMI-2 specimen expertenced were based on the following microstructural observations:

- Start of $\alpha \rightarrow \gamma$ transformation at $\mathrm{Ac}_{1}$ temperature $\left(727^{\circ} \mathrm{C}\right.$ quoted).

- Dissolution of dark feathery band at the cladding/base metal interface between 800 and $925^{\circ} \mathrm{C}$, depending on time at temperature.

- Formation of small equiaxed grains in the A533 Gr. B steel HAZ adjacent to the interface between 850 and $900^{\circ} \mathrm{C}$. These small grains disappear, as a result of grain growth, between 1025 and $1100^{\circ} \mathrm{C}$.

- $\delta$-ferrite islands in the cladding spheroldize in the range of $975-1000^{\circ} \mathrm{C}(100$ $\mathrm{min})$ or $1100-1125^{\circ} \mathrm{C}(10 \mathrm{~min})$.

\subsection{Reaustenitization of A533 Gr. B Head Material}

Figure 5 in Diercks ${ }^{6}$ is a CCT diagram of an equivalent grade of German steel. According to this diagram, the lower critical temperature $(A C)$ is $715^{\circ} \mathrm{C}$ (at a heating rate of $0.4^{\circ} \mathrm{C} / \mathrm{min}$ ) and the upper critical temperature is $850^{\circ} \mathrm{C}$. A CCT diagram for ASTM A533 Gr. B is also presented in a paper by Kunitake et al.7. reproduced here as Fig. 6, which shows that the lower and upper critical temperatures are 720 and $830^{\circ} \mathrm{C}$, respectively. Although neither CCT diagram in Diercks (Figs. 4 and 5 in Ref. 6) gives hardnesses for the various cooling rates, they are given in Kunitake's CCT diagram, shown as Fig. 6. Although the Korth report does not state the composition of the lower head, the composition is given in Ref. 6; however the latter document lists erroneous carbon check analyses (see Table 1). The Lukens data reported in Ref. 6 indicated a carbon content of 0.22 wt.\%. The maximum hardness of martensite in a quenched $0.22 \% \mathrm{C}$ steel would be $45 \mathrm{HRC}$ ( $446 \mathrm{HV}$, converted).

Hardness testing (Rockwell B converted to Vickers) was used for the initial screening of specimens and was very effective in showing that four were quite different 


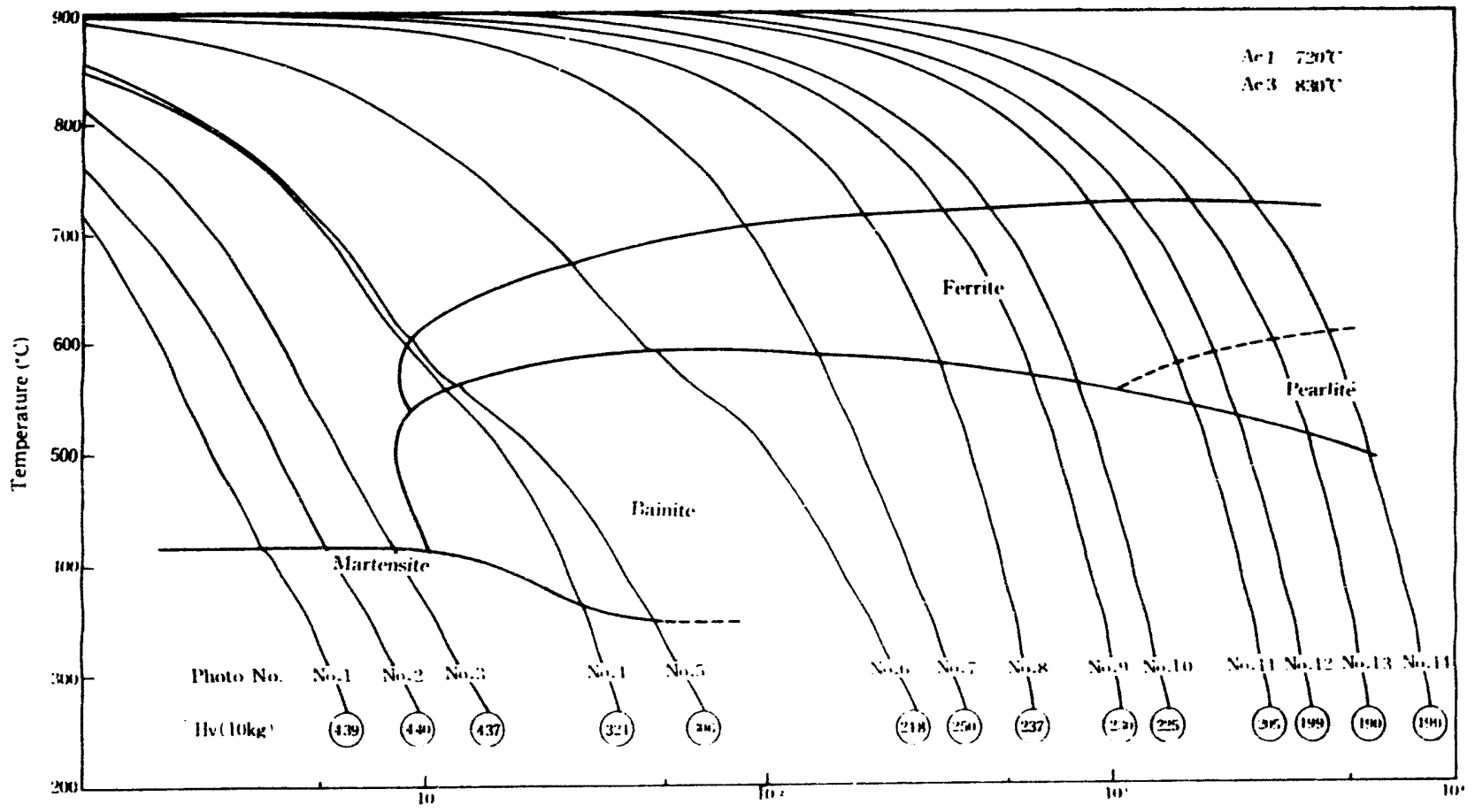

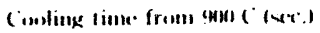

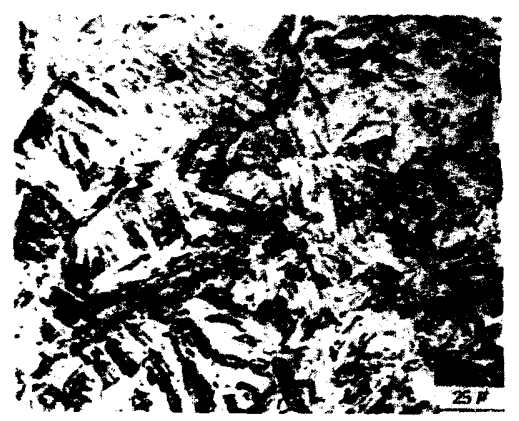

1. $1.14 \times 1<\mathrm{min}$

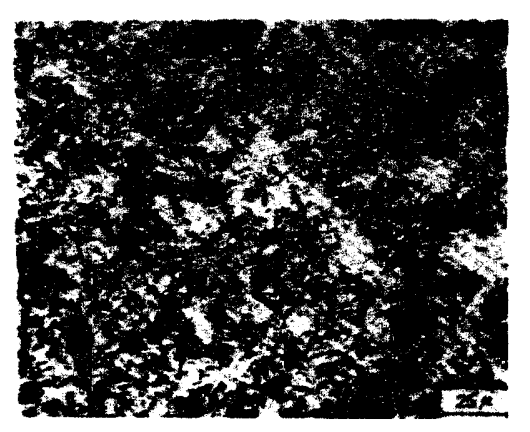

No. $4 \quad 815^{\circ} \mathrm{C}_{i} \min$

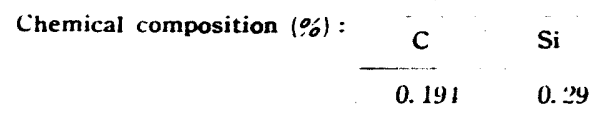

Austenitizing : $100-\mathrm{C}-12 \mathrm{~min}$

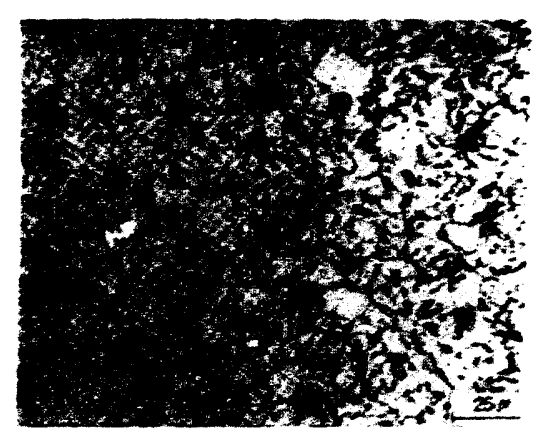

No. $1025-C_{i} \min$

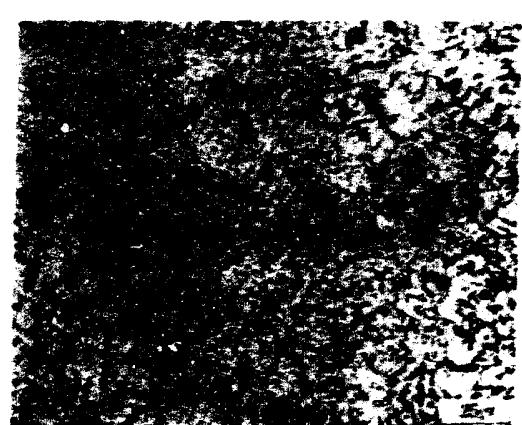

No. $935 \cdot \mathrm{C}$ min

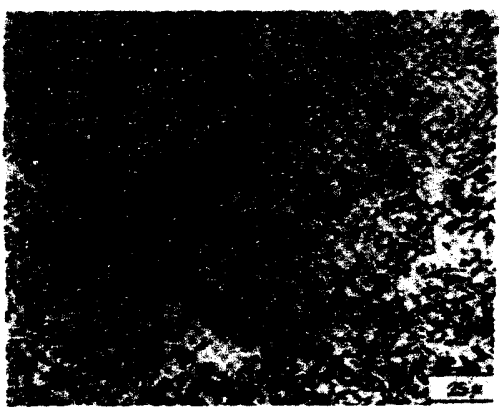

No. T $125^{\circ} \mathrm{C} \mathrm{min}$

Ni Mo Al N

0.5

0.38 (1) 0.3

U. (x):

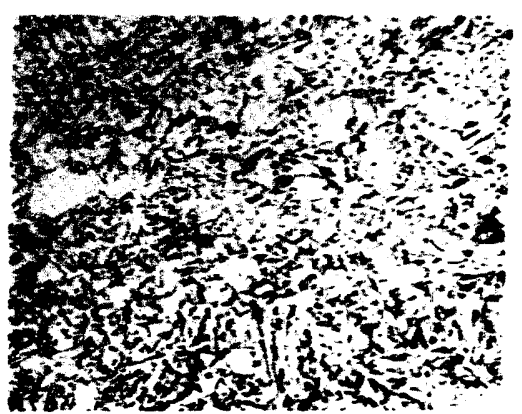

No. : .........

Fig. 6. Continuous-cooling-transformation (CCT) diagram for A533 Grade B steel (from ref. 7, used by permission of Nippon Steel Corp.). 
Table 1. Carbon and $\delta$-ferrite data

\begin{tabular}{|c|c|c|c|}
\hline Source & Specimen & $\begin{array}{l}\text { Carbon Content } \\
\text { (wt.\%) }\end{array}$ & $\begin{array}{l}\text { 8-Ferrite Content } \\
\text { (vol.\%) }\end{array}$ \\
\hline Lukensa & - & 0.22 & - \\
\hline Diercksa & Analysis 1 & 0.28 & - \\
\hline Diercksa & Analysis 2 & 0.25 & - \\
\hline Diercksa & Analysis 3 & 0.25 & - \\
\hline Diercksa & Analysis 4 & 0.25 & - \\
\hline Spainb & $M-11$ (m6) & - & 4.5 \\
\hline Spain $b$ & $\mathrm{~K}-7$ (m5) & - & 4.5 \\
\hline Spain $b$ & E-8 (m6) & - & 1.4 \\
\hline Germanyc & F-5 (m6) & 0.22 & 4.0 \\
\hline Germanyc & E-8 (m9) & 0.21 & 1.4 \\
\hline Germanyc & $\mathrm{K}-13$ (m5) & 0.22 & 5.0 \\
\hline Germanyc & L-9 (m9) & 0.22 & 4.5 \\
\hline Germanyc & M-8 (m4) & 0.22 & 4.0 \\
\hline Germanyc & $M-11(\mathrm{~m} 5)$ & 0.22 & 5.0 \\
\hline Germanyc & $\mathrm{H}-4(\mathrm{~m} 5)$ & 0.22 & 5.0 \\
\hline Germanyc & H-5 (m5) & 0.22 & 5.0 \\
\hline Germanyc & $\mathrm{K}-7$ (m6) & 0.22 & 4.5 \\
\hline
\end{tabular}

aFrom Ref. 6, Table 16.

bFrom Ref. 13.

cFrom Ref. 14.

from the rest (which were similar in hardness to the non-exposed archive material). Hardness testing of the archive material revealed a low hardness in the cladding which increased at the interface and reached a peak value $2-4 \mathrm{~mm}$ below the interface. The hardness then decreased, reaching a rather constant lower hardness at $\approx 10 \mathrm{~mm}$ below the interface down to $\approx 40 \mathrm{~mm}$. Four specimens, G-8, F-10, E-6, and E-8, exhibited different results. For E-8 and F10, the peak hardness was much higher and was obtained at $\approx 6 \mathrm{~mm}$ below the interface (this area could not be tested on the E-6 and G-8 specimens). Testing at greater depths revealed little or no loss in hardness, unlike the archive specimens and the other TMI-2 specimens. A533 Gr. B head material in these four specimens was reaustenitized during the incident, that is, the temperature exceeded the upper critical temperature. The cooling rate was fast enough to form bainite, rather than ferrite and pearlite, but not fast enough to form martensite (which would have been harder, $=440 \mathrm{HV}$ ). The microstructural appearance was consistent with bainite also. This work showed that the steel in these four specimens was reaustenitized to a depth of at least $40 \mathrm{~mm}$ below the cladding. i.e., the temperature exceeded $830-850^{\circ} \mathrm{C}$ to a depth of more than $40 \mathrm{~mm}$. 
The hardness tests were very useful and the results thereof were valid. However, it would have been better to do all of the tests with a Vickers indenter and a load of 10 kgf rather than with the Rockwell $B$ tester and converting the data to Vickers. The upper limit of the Rockwell B scale is $100 \mathrm{HRB}$, about $240 \mathrm{HV}$. Because some of the hardness measuremenis exceeded these limits, use of the HRB scale should have been avoided. Further, there are no approved conversion scales for HRB to HV for hardnesses greater than $100 \mathrm{HRB}$ and there are no approved conversion scales between HRB and HV for austenitic stainless steels.

Figure 6, for an A533 Gr. B steel with 0.19\% C, which would have a maximum martensitic hardness of $44 \mathrm{HRC}$ ( $434 \mathrm{HV}$, converted), shows that the experimentally developed hardnesses for cooling rates that produced only martensite were 437-440 $\mathrm{HV}\left(10 \mathrm{kgf}\right.$ load). For a cooling rate of $125^{\circ} \mathrm{C} / \mathrm{min}$, Fig. 6 shows a hardness of $250 \mathrm{HV}$ (Curve 7). A cooling rate of $65^{\circ} \mathrm{C} / \mathrm{min}$ (Curve 8, Fig. 6) gave a hardness of $237 \mathrm{HV}$. A cooling rate of $35^{\circ} \mathrm{C} / \mathrm{min}$ (Curve 9, Fig. 5) gave a hardness of $230 \mathrm{HV}$. These structures were all bainitic.

According to Fig. 3 in Korth, 2 Samples G-8, F-10, E-8 and E-6 were all reaustenitized during the event and transformed subsequently to a bainitic structure with a hardness of 250-275 HV from a depth of $\approx 5$ to $40 \mathrm{~mm}$ below the interface. According to Fig. 5 of Korth, ${ }^{2}$ these hardnesses would be produced by a cooling rate from the $\gamma$ region of $=50^{\circ} \mathrm{C} / \mathrm{min}$ for austenitizing temperatures from 800 to $1100^{\circ} \mathrm{C}$, or for slower cooling rates for peak temperatures of $1000-1100^{\circ} \mathrm{C}$. The CCT diagram of Kunitake et al., 7 shown attached as Fig. 6, was developed using a $920^{\circ} \mathrm{C}$ austenitizing temperature. These findings suggests that the cooling rates required to produce a 250-275 HV bainitic structure would be somewhat $>125^{\circ} \mathrm{C} / \mathrm{min}$, not in perfect agreement but reasonably close.

\subsection{Grain Growth in Heat-Affected Zone}

Observations of the prior-austenite grain size (PrGS) in the specimens was qualitative and appears to have been of minor value in establishing the thermal exposure history of the specimens. The PyGS in the as-clad and stress-relieved head would vary because of the cladding process. Next to the fusion line, the grains will be quite coarse because the $\gamma$-grain coarsening temperature was exceeded. The PyGS will become finer going away from the fusion line towards the region where the temperature just reached the Ac3. The stress relief treatment will not alter this grain pattern. However, subsequent reheating above the $A c_{1}$ will alter the pattern. The former coarse-grain region will recrystallize somewhat non-uniformly. The heating during the incident was not isothermal, but gradient. Consequently, when a temperature gradient is placed on the microstructure, with its gradient in grain size. recrystallization will be faster in some regions than in others.

The Korth report ${ }^{2}$ made very little use of variations in the PyGS of the A533 Gr. B head. Special etchants ${ }^{8}$ should have been used to preferentially delineate the boundaries. Then, a lineal analysis approach, with the line parallel to the interface, could have been used to measure the PYGS as a function of the distance from the 
interface. These measurements can be made with precision, despite the claim by Korth $^{2}$ (p. 19) that they cannot be made with precision. Although the aluminum content of the head was nut well defined (the Lukens analysis in Ref. 6 does not list a value), it appears to be in the region of $0.02-0.04 \mathrm{wt} \%$. This would give a graincoarsening temperature of $970-1020^{\circ} \mathrm{C} .9 .10$

\subsection{The "Carbon-Diffusion Zone"}

Korth ${ }^{2}$ noted the presence of a zone in the cladding, adjacent to the interface in Specimens F-10 and E-8, which he called a "carbon-diffusion zone." "SEM microchemical analysis" proved that the zone was enriched in carbon, apparently from the A533 Gr. B substrate. Korth stated that the hardness of this zone was "up to 500 DPH" and that it contained microcracks, indicating that it was brittle. However, the exact nature of this zone was not defined. It is not martensitic in appearance, and a $0.22 \% \mathrm{C}$, as-quenched martensite would not produce $500 \mathrm{HV}$ anyway. Convergent beam electron diffraction of the extracted particles, and perhaps of the matrix using thin folls, is required to properly identify this zone. A complete Identification of this zone might shed more light on the thermal history of these specimens. Selective etchants might be quite helpful. It is possible that sigma phase may be present in this zone. The brittleness of the sigma phase, 11.12 its ability to form from $\delta$-ferrite in austenitic stainless steel welds, and its hardness all make this a possibility.

\subsection{Interfacial Dark Etching Zone}

Korth 2 noted that the dark feathery band at the interface was not present in the E-8 and F-10 specimens (the interface was ground away on the E-6 and G-8 specimens during decontamination but examination in the ANL hot cell did not reveal the dark band). It was present on the archive specimens and all TMI-2 specimens belleved to have seen temperatures $\angle A c_{1}$. The exact nature of this zone was not determined. Korth (Ref. 2, p. 19) believed that "it appears to be some sort of carbide." The microhardness of this zone was not stated. As it was quite narrow, the HRB tests probably did not assess its hardness. From the photo-micrographs, it appears that the dark feathery band is a smooth line on the A533 Gr. B side and ragged on the Type 308 stainless steel side. This zone is where dilution has occurred between the two alloys, producing some intermediate composition. Whatever the initial structure was, lath martensite and lower bainite are two possibilities; the structure was dissolved upon heating above the $\mathrm{Ac}_{3}$.

\subsection{Carbon-Free/Carbide-Free Equiaxed Grains}

In his second conclusion (Ref. 2, p. 20), Korth states that carbon diffusion from the alloy steel into the stainless cladding was observed in the accident heat-affected samples (F-10 and E-8) and that this was the mechanism for dissolution of the feathery carbide band and the formation of the cementite-devoid equiaxed grains. However, the nature of the dark feathery band in the weld dilution zone was never

established. It was not proved to be from carbides (Why would this zone etch dark if 
It were predominantly carbide?). The dark feathery band was more likely lower bainite or lath martensite tempered from the stress relief. The dilution zone would not be rich enough to be fully austenitic but its hardenabllity would be much greater than that of the A533 Gr. B head material, so martensite or lower bainite could easily form at these low cooling rates after cladding. If they had been carbides, why would a feathery structure persist after the $50 \mathrm{~h}$ hold at $610^{\circ} \mathrm{C}$, which would surely cause spheroidization?

Furthermore, no evidence of cementite-devold equiaxed grains is present in any TMI-2 specimen, F-10 and E-8 included. The hardness profles in Fig. 3 of Korth 2 are not consistent with carbon- or carbide-free ferrite grains but with upper bainite, as shown in the photo-micrographs of E-8 and F-10 in Appendixes A and C of Ref. 2. In contrast, ferrite grains essentially free of cementite appear to be present below the interface in the Midland archive specimens (Appendix B of Ref. 2) heated at 900 and $1000^{\circ} \mathrm{C}$. The $1100^{\circ} \mathrm{C}-1 \mathrm{~min}$ specimen has equiaxed, carbon-free ferrite grains, but other grains appear to contain carbides while those held for 10 and 100 min appear to contain carbides. In this respect, the isothermally heated archive specimens do not appear to match the gradiently heated TMI-2 F-10 and E-8 specimens.

\subsection{Spheroidization of $\delta$-Ferrite}

Korth 2 noted that reheating to $1000^{\circ} \mathrm{C}$ for $100 \mathrm{~min}$, or $1100^{\circ} \mathrm{C}$ for $10 \mathrm{~min}$, dissolved the $\mathrm{M}_{23} \mathrm{C}_{6}$ carbide at the $\gamma-\delta$ interface and spheroidized the $\delta$; he did not note a reduction in the percentage of $\delta$ due to spheroidization. The Spanish 13 and Germe!n 14 independent studies both reported 1.4 vol.\% $\delta$ (by magnetic tests rather than by metallography) in the E-8 specimens (m-6 and m-9 specimens, respectively) compared to 4 to 5 vol. $\% \delta$-ferrite in speci $n$ ns that were heated to $\angle A c_{1}$. Table 1 lists their data.

The spheroidization of $\delta$-ferrite in austenitic stainless steel welds has been studied 15 for Type 316 (carbon content actually meets $316 \mathrm{~L}$ ) stainless steel. Figure 7 shows how the ferrite content decreases with time and temperature. In this work, $\mathrm{f}_{0}$ was the initial ferrite content $(9 \%)$, and $f$ is the ferrite content remaining after exposure to high temperature. For the E-8 specimen, $f / f_{0}$ would be in the range of 0.28 to 0.35 . If our time at temperature was limited to $<60 \mathrm{~min}$. Fig. 7 would indicate that temperatures of $1050-1100^{\circ} \mathrm{C}$ would be required, assuming that Type 308 responds the same as Type 316L stainless steel. This is in good agreement with Korih's conclusion for Specimen E-8.

Raghunathan et al.15 also examined the shape change with temperature and time (Fig. 8). The shape factor used, D/L, is the ratio of the average diameter to the length of the $\delta$ particles. A D/L of 1 (1.e., 100 in Fig. 8) represents a particle with a perfectly circular cross section. Again, for times $<60 \mathrm{~min}$, pronounced spheroidization requires temperatures of $1050-1100^{\circ} \mathrm{C}$.

Spruiell et al. 16 have shown that the $\delta$ ferrite content in Type 308 weld metal will be reduced at even lower temperatures. For example, aging at $750^{\circ} \mathrm{C}$ for $2 \mathrm{~h}$ reduced 


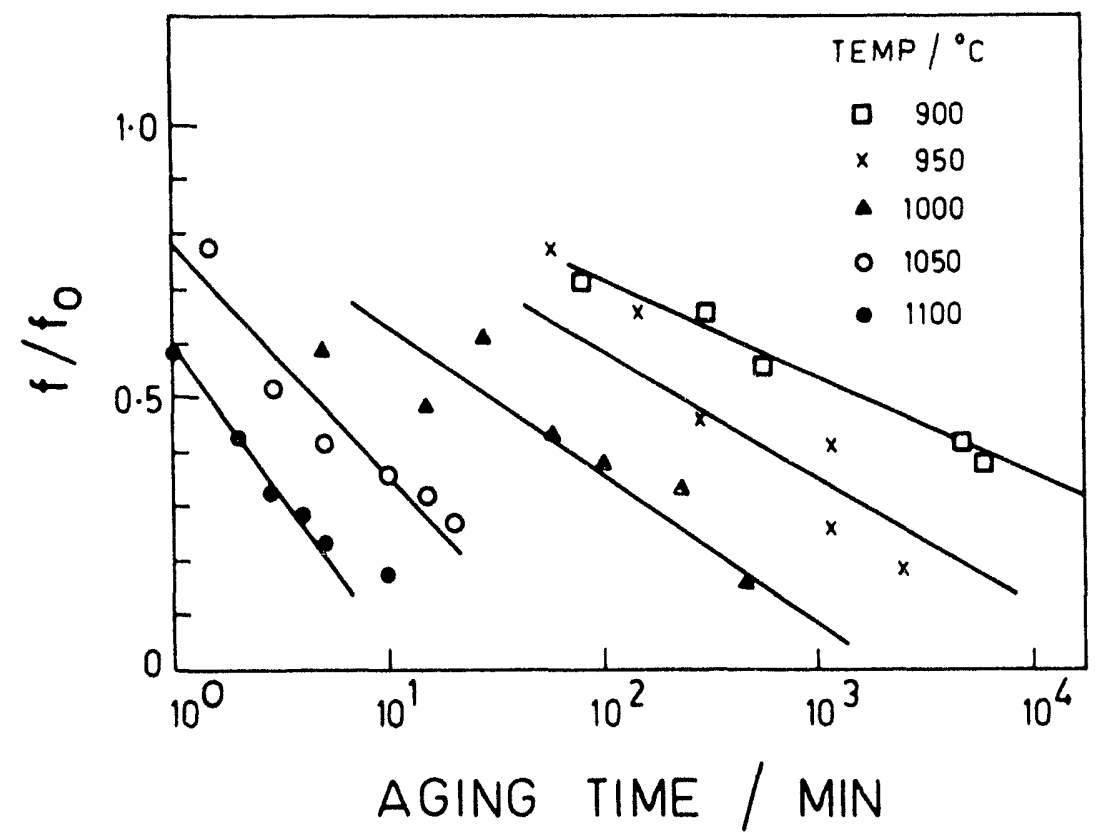

Fig. 7. Variation of fraction of $\delta$-ferrite remaining with the logarithm of the aging time at various temperatures (from Ref. 15, used by permission of ASM International).

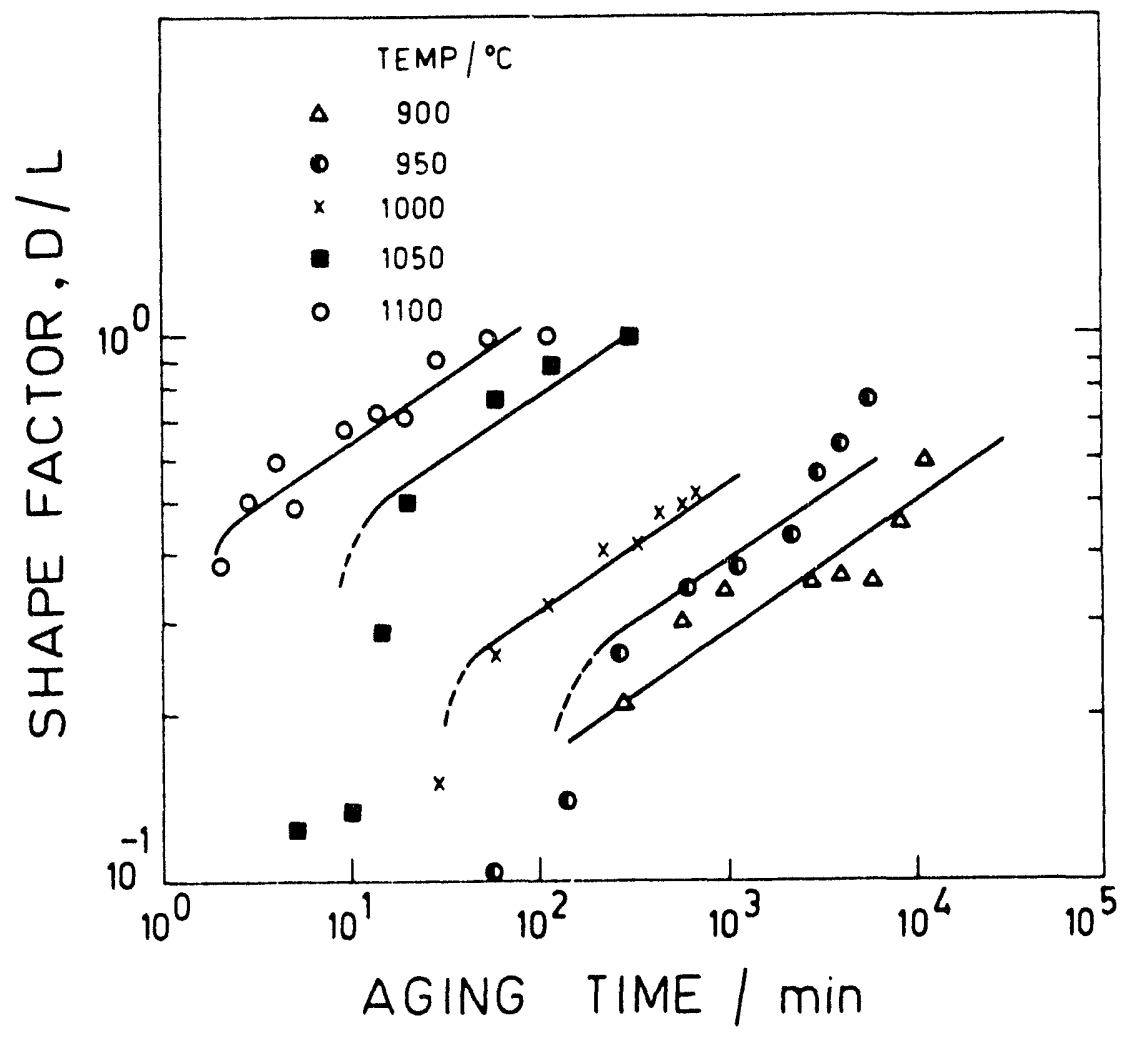

Fig. 8. Variation of the shape factor $\mathrm{D} / \mathrm{L}$ with aging time at various temperatures (from Ref. 15, used by permission of ASM International). 


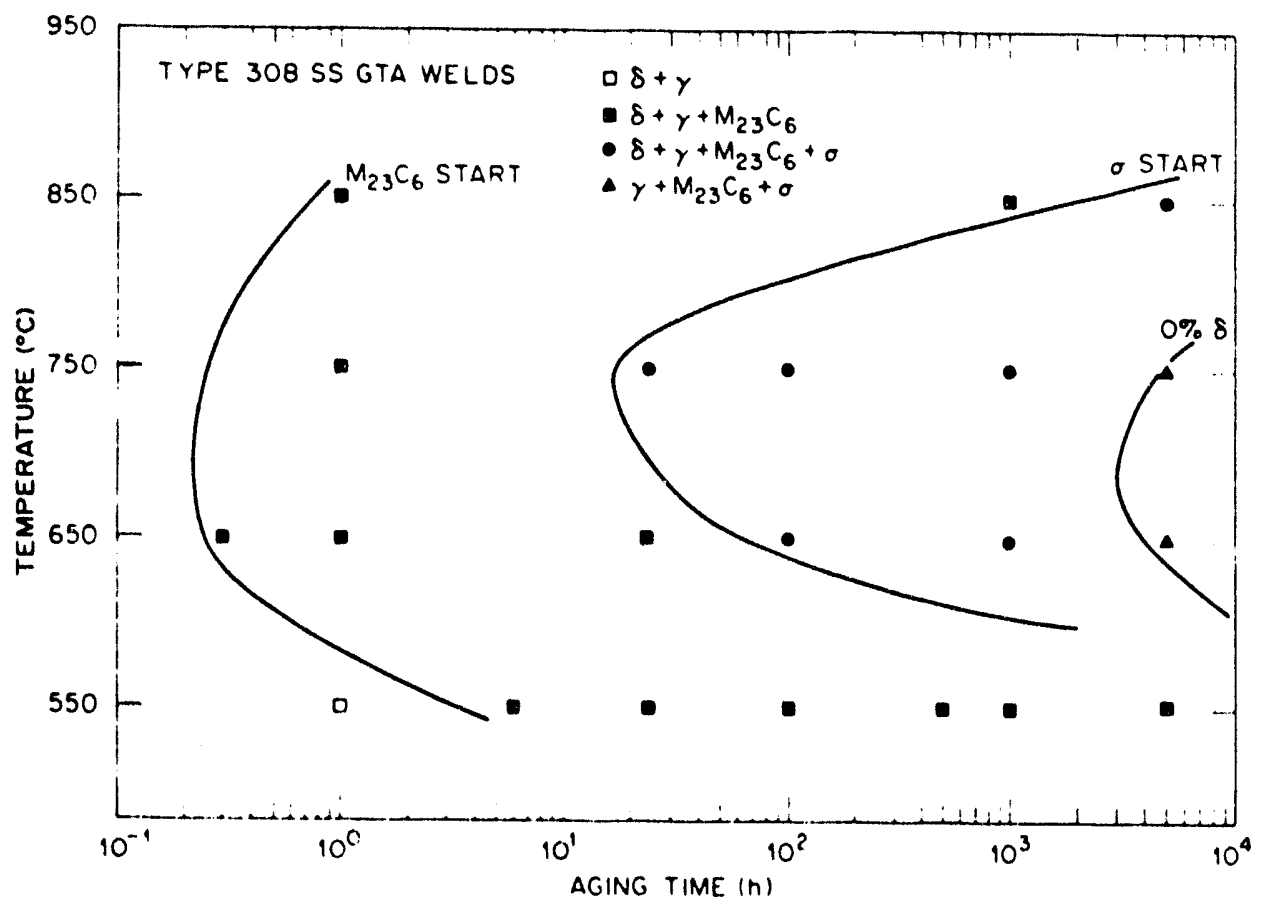

Fig. 9. Time-temperature-precipitation (TTP) diagram for welded and aged Type 308 stainless steel (from Ref. 18, used by permission of the American Welding Society).

the ferrite content by more than $60 \%$. Vitek and David 17 performed electron microprobe analyses of delta ferrite in aged 308 welds. They showed that, with increasing temperature, the $\mathrm{Cr}$ content of the $\delta$ decreased and the Ni content of the $\delta$ increased. Vitek and David ${ }^{18}$ also studied the influence of aging temperatures (550: $850^{\circ} \mathrm{C}$ ) upon the ferrite content of Type 308 weldments. They found that the rates of ferrite transformation at 650,750 , and $850^{\circ} \mathrm{C}$ were nearly the same. Aging for $1 \mathrm{~h}$ reduced the ferrite level to $60-70 \%$ of the initial level. Aging at $550^{\circ} \mathrm{C}$ had little effect on the ferrite content. Aging at these low temperatures generally produces precipitation of $\mathrm{M}_{23} \mathrm{C}_{6}$ carbide. The stress relief operation $\left(50 \mathrm{~h}\right.$ at $\left.610^{\circ} \mathrm{C}\right)$ causes transformation of some of the as-clad ferrite content and precipitation of carbide at the $\gamma-\delta$ interfaces. Figure 9 shows the TTP curve of Vitek and David for precipitation in Type 308 weldments. 18 This plot shows three carbon curves, one for the start of $\mathrm{M}_{23} \mathrm{C}_{6}$ precipitation, one for the start of $\delta$ precipitation, and the third for the completion of the $\delta$-ferrite transformation. According to this diagram, $\delta$ precipitation is fastest at $750^{\circ} \mathrm{C}$, with the reaction starting after $20 \mathrm{~h}$. Time-temperatureprecipitation diagrams for ferritic (and also for nonferrous) alloys have recently been collected and published; 19 these diagrams can be very useful aids.

Horton et al. ${ }^{20}$ showed that $\mathrm{M}_{23} \mathrm{C}_{6}$ would precipitate in $\approx 10$ minutes at 750 $800^{\circ} \mathrm{C}$ in Type 316 stainless steel. Beckitt ${ }^{21}$ showed that $\delta$ would form in $1 \mathrm{~h}$ at $750^{\circ} \mathrm{C}$ in a $24.85 \% \mathrm{Cr}-8 \% \mathrm{Ni}$ austenitic alloy. It is well known that $\sigma$ forms much more rapidly from $\delta$ than from $\gamma$. Barcik 22 showed that the rate of precipitation of $\sigma$ from $\delta$ ferrite was almost two orders of magnitude faster than from austenite. Weiss 
and Stickler 23 studied phase precipitations in wrought, solution-annealed Type 316L austenitic stainless steel. They noted that $\mathrm{M}_{2} \mathrm{C}_{6}$ forms most rapidly at grain boundaries, less rapidly at incoherent twin boundaries, and slowest at coherent twin boundaries. Smith and Farrar ${ }^{24}$ have recently reviewed microstructure-compositionmechanical property relationships in austenitic, 300 series weldments.

\subsection{Cladding Cracks}

Korth ${ }^{2}$ reported that cracks were observed in the cladding of Specimens E-6 and G-8. Because of difficulties in decontaminating these specimens, the cladding had to be removed and the microstructure was not avallable for Korth to examine and document. Cladding crack locations were mapped by Diercks (Fig. 30 in Ref. 6) showing that they were in the E-7 and G-6 quadrants, but none were in the G-8 quadrant. Specimen E-6 was ortented diagonally across the E-7 and F-6 quadrants and contained some of the corner of the E.6 quadrant. Specimen F-5 was the nearest one to the G-6 quadrant but its cladding was not cracked. In Fig. 2 of Ref. 2, Korth mapped out the location of the apparent hot spot on the lower head. If we assume that Fig. 30 of Ref. 6 was in error regarding G-6 vs. G-8, we must conclude that the cracking was a result of the high temperatures experienced in this region. It is possible that the cladding cracks formed as a result of the spheroldization and dissolution of the $\delta$ in this region, perhaps in a manner analogous to hot cracking in austenitic stainless steel welds that do not contain the critical amount (3-8\%) of $\delta$. Unfortunately, the clad surfaces of E-6 and G-8 were removed, so the degree of spheroidization and dissolution of the $\delta$ cannot be determined.

\subsection{Conclusions}

The overall approach of the Korth report ${ }^{2}$ was sound. However, all of the observations were qualitative in nature, nothing was quantifled. The overall conclusions appear to be reasonable, although it is difficult to disagree with qualitative data. Had the structures been quantified, then the conclusions could be debated or accepted objectively.

A weakness of the conclusions is that (p. 15, Ref. 2) all three areas (cladding, interface and low-alloy steel) of the standards were compared to those of the TMI-2 specimens. However, the standards were heated isothermally, but the reactor specimens were heated gradiently. Thus, the three areas of the TMI-2 specimens should be compared individually with those same areas of any of the control specimens. We should not expect to see conformance among these three areas of the unknowns with those of any single standard. Also, isothermal heating of Midland specimens at 900 and $1000^{\circ} \mathrm{C}$ produced carbon- and carbide-free equiaxed ferrite grains below the cladding interface, which were not present in the gradiently heated TMI-2 specimens.

Korth concluded (p. 15 of Ref. 2) that E-8 experienced $1100^{\circ} \mathrm{C}$ for $10-30 \mathrm{~min}$ $\left(1075-1100^{\circ} \mathrm{C}\right.$ for $30 \mathrm{~min}$, on p. vil and p. 20) while $\mathrm{F}-10$ experienced $1050^{\circ} \mathrm{C}$ (or $1040-1060^{\circ} \mathrm{C}$, p. vil and p. 20) for $30 \mathrm{~min}$. He also concluded that the thermal 
excursion on the lower head was -30 minutes (p. 19, Ref. 2). The basis of this latter conclusion was not given in the report. We assume that it was based on the event history, rather than on observations made by Korth in his study. Examination of the cladding of the control specimens for $1100^{\circ} \mathrm{C}$ suggests that the degree of $\delta$-ferrite dissolution and spheroidization in E-8 is more typical of the 100-min exposure at $1100^{\circ} \mathrm{C}$ than of a $10-30 \mathrm{~min}$ exposure. It is also possible that this specimen experienced a somewhat higher temperature, if the thermal excursion was limited to $30 \mathrm{~min}$.

The use of special etchants and quantitative microscopy would have added precision to this study, although the final conclusions may not have been that much different. The prior austenite grain boundaries in the A533 Gr. B head could have been preferentially delineated and the grain size could have been measured as a function of depth below the interface. This would be repeated using the standards. The grain size at any depth below the surface as a function of reheat temperature could be plotted and used to determine the temperature profile of the unknowns. Lkewise, selective etchants could have been applied to the cladding to see what the structure of the carbon-diffusion zone was. Convergent beam electron diffraction by Auger electron microscopy would also be required. If $\sigma$ or some carbide type other than $\mathrm{M}_{23} \mathrm{C}_{6}$ was detected, then this might lead to other conclusions. The $\delta$ phase in the cladding could be quantified and compared with that of the standards to better define the thermal exposure. Microprobe analysis of the $\delta$ could be made as well, as was done by Vitek and David. ${ }^{17}$ With these types of measurements avallable, the conclusions as to thermal exposure should be definitive. 
1. J. R. Wolf and J. L. Rempe, compilers, TMI-2 Vessel Investigation Project Integration Report, TMI V(93) EG10, Idaho National Engineering Laboratory, October 1993.

2. G. E. Korth, Metallographic and Hardness Examinations of TMI-2 Pressure Vessel Samples, TMI V(92) EG01, Idaho National Engineering Laboratory, Jan. 1992.

3. D. R. Diercks and L. A. Neimark, Results of Mechanical Tests and Supplementary Metallographic Examinations of the TMI-2 Lower Head Samples, TMI V(93) AL02. Argonne National Laboratory, June 1993.

4. L. A. Neimark, T. L. Shearer, A. Purohtt, and A. G. Hins, TMI-2 Instrument Nozzle Examinations at Argonne National Laboratory. TMI V(93) AL01, Argonne National Laboratory, February 1993.

5. Republic Alloy Steels, Republic Steel Corp., Cleveland, OH (1961), p 96.

6. D. R. Diercks, TMI-2 Vessel Investigation Project (VIP) Metallurgical Program. Progress Report October 1989.June 1990, NUREG/CR-5524, ANL-90/34, Vol. 2, November 1990.

7. H. Kunitake et al., Manufacture and Properties of Heavy Section Steel Plates for Nuclear Reactor Pressure Vessels, Nippon Steel Tech. Report, Overseas No. 7. November 1975, pp. 1-20.

8. G. F. Vander Voort, Metallography: Principles and Practice, McGraw-Hill Book Co., New York, 1984, pp. 219-223, 638-640.

9. T. Gladman and F. B. Pickering, Grain-Coarsening of Austenite, JISI, Vol. 205, 1967, pp. 653-664.

10. F. G. Wilson and T. Gladman, Aluminium Nitride in Steel, Intl. Mat. Rev., Vol. 33, 988, pp. 221-286.

11. L. K. Poole, Sigma-An Unwanted Constituent in Stainless Weld Metal, Met. Progress, Vol. 65, 1954, pp. 108-112.

12. G. F. Vander Voort, Embrittlement of Steels, Metals Handbook, 10th ed., Vol. 1, ASM International, Materials Park, OH, 1990, pp. 689-736.

13. L. Pedrero and P. Veron, Metallographic Investigation of TMI-2 Lower Pressure Vessel Head Samples, TMIV(92) E002, Equipos Nucleares S.A., Miliaño, Spain (April 1992).

14. H. Ruoff, K.-H. Katerbau, and D. Sturm, Metallographic Examination of TMI-2 Lower Pressure Vessel Head Samples, TMIV(91) D001, Staatliche Materialprüfungsanstalt Stuttgart (September 1991). 
15. V. S. Raghunathan et al., The Influence of Post Weld Heat Treatments on the Structure, Composition and the Amount of Ferrite in Type 316 Stainless Steel Welds, Met. Trans., Vol. 10A, 1979, pp. 1683-1689.

16. J. E. Spruiell et al., Technical Note: Ferrite Stability at Elevated Temperatures in Austenitic Stainless Steel Weld Metal, Welding J., Vol. 56, 1977, pp. 289s-290s.

17. J. M. Vitek and S. A. David, Metastable Equilibrium of Ferrite in Type 308 Stainless Steel, Scripta Met., Vol. 19, 1985, pp. 23-26.

18. J. M. Vitek and S. A. David, The Solidification and Aging Behavior of Types 308 and 308CRE Stainless Steel Welds, Welding J., Vol. 63, 1984, pp. 246s-253s.

19. G. F. Vander Voort, Atlas of Time-Temperature Diagrams for Irons and Steels, ASM International, Materials Park, OH, 1991.

20. C. A. P. Horton et al., Time-Dependent Changes in Microstructures and Mechanical Properties of Type 316 Steel and Weld Metal, in Mechanical Behaviour and Nuclear Applications of Stainless Steel at Elevated Temperatures, The Metals Soc., London, Book 280, 1982, pp. 66-72.

21. F. R. Beckitt, The Formation of Sigma-Phase from Delta-Ferrite in a Stainless Steel, JISI, Vol. 207, 1969, 632-638.

22. J. Barcik, The Kinetics of $\sigma$-Phase Precipitation in AISI 310 and AISI 316 Steels, Met. Trans., Vol. 14A, 1983, pp. 635-641.

23. B. Weiss and R. Stickler, Phase Instabilities During High Temperature Exposure of 316 Austenitic Stainless Steel, Met. Trans., Vol. 3, 1972, pp. 851-866.

24. J. J. Smith and R. A. Farrar, Influence of Microstructure and Composition on Mechanical Properties of Some AISI 300 Series Weld Metals, Int. Mat. Rev., Vol. 38, No. 1, 1993, pp. 25-51. 


\section{Curriculum Vitae}

Robert W. Bohl

Areas of Expertise: $\quad$ Physical Metallurgy, Fallure Analysis, Microstructure Interpretation, Mechanical Properties

Education:

B.S. Metallurgical Engineering, Univ. of Illinois, 1946

M.S. Metallurgical Engineering, Univ. of Illinois, 1949

Ph.D. Metallurgical Engineering, Univ, of Illinois, 1956

\section{Employment:}

University of Illinois, College of Engineering

Instructor, Metallurgical Engineering

1946-1949

Assistant Professor

$1949-1956$

Associate Professor

$1956-1959$

Professor

$1959-1962$

Professor, Met. Engr. \& Nuclear Engineering

$1962-1981$

Professor Emeritus

1981-present

\section{Honors and Awards}

Tau Beta Pi, Sigma Xi, Alpha Sigma Mu (International President, 1970-71), Phi Kappa Phi, Pierce and Everitt Awards (Univ of Illinois), Who's Who in America, A. E. White Award (ASM International)

Professional Societies

American Society for Metals (Fellow), American Nuclear Society, American Society for Engineering Education, American Association for Advancement of Science

\section{Courses Taught}

Ferrous Physical Metallurgy, Nonferrous Physical Metallurgy, Phase Diagrams, Mechanical Metallurgy, Metallography, Fabrication of Alloys, Design of Engineering Alloys, Nuclear Power Engineering, Nuclear Metallurgy, Introduction to Metallurgy

\section{Other Professional Employment}

Summer Appointments, Argonne National Laboratory, Battelle Memorial Institute, Ames Laboratory, U.S. Steel, Hanford Laboratory, Caterpillar, Inc.; Adjunct Faculty, ASM International, Consultant, Alloy Engineering \& Casting, in addition to numerous industrial, insurance, and legal firms

\section{Technical Publications in Various Journals}

American Welding Society Journal; American Chemical Society Journal; Journal of Nuclear Materials; Review of Scientific Instruments; University of llinois Experiment Station Bulletin Series; Heat Treating; Transactions, American Nuclear Society. 


\section{Richard G. Gaydos}

\section{Education:}

B.S., Metallurgical Engineering, University of Illinois, Urbana, IL

Graduate work, Illinois Institute of Technology. Chicago, IL

Graduate, Corps of Aviation Cadets, U.S. Alr Force

\section{Emplosment:}

Republic Steel Corporation. Positions held Include Supervisor, Research and Investigation Laboratories; Laboratory Director; Assistant Chief Metallurgist; Corporate Consultant

\section{Corporate Activities:}

Chairman, Corporate Surface Quality Committee

Chairman, Corporate Conditioning \& Inspection Committee

Chairman, Corporate Chief Chemists Committee

Member, Corporate Cold Forming Committee

Member, Corporate Free Machining Steel Committee

Member, Task Group on Conditioning and Inspection

Member, Task Group on Tubular Products Quality

Co-author, Republic Alloy Handbook

Instructor, Human Engineering Educational Institute

\section{Professional Societies:}

ASTM, ASM International, AIME, AISI, ANSI, British Iron and Steel Institute, Association of Iron and Steel Engineers

\section{Professional Soclety Committee Activities:}

Past National Chairman, ASNT Technical Council

Past Member, ASNT National Board of Directors

Past Vice-Chairman, ASNT Education and Qualification Council

Member and past member of numerous ASNT technical committees

ASTM Main Committee Member, E-46 (Quality Provisions in ASTM Standards)

ASTM Main Committee Member, E-4 (Quality Control)

ASTM Main Committee Member, E-7 (Nondestructive Testing)

Chairman, ASTM Sub-committee E-46.03.05 (Penetrant Standard Photographs)

Member and past member of numerous ASTM subcommittees

Member, SAE Committee K (Magnetic Particle and Penetrant Task Group)

Past Member, ASM and AIME local chapter Executive Committees

Past Member, AISI Company Member Council

Awards:

Alpha Sigma Mu (national honorary metallurgical society)

1982 Distinguished Merit Award, U. of Illinois Dept. of Mining and Metallurgical

Eng.

Fellow, ASNT

ASM Distinguished 25-year Award

ASM Honorarial Speaker, First World Conference on Failure Analysis

Certified Expert Witness for Fallure Analysis and Metallurgical Engineering 


\section{Publications:}

Republic Alloy Steels Handbook, 1961 edition, co-author

Republic Alloy Steels Handbook, 1968 edition, co-author

The Effect of Composition in Causing Surface Breaks During Blooming, Bar and Allied Products, Vol. 13, AIME (1961)

Failure in Heavy Machinery, Metal Eng. Quarterly, Vol. 3 (1963)

The Morphological Effects of Some Non-Metallics in Free Machining Steels, Mechanical Working of Steels, Vol. 26 (1964)

Making and Selection of Steels for Cold Forming, Met. Progress, Vol. 87 (1965)

Cold Forging...Theory is Catching up With Practice, JSAE, Vol. 73 (1965)

Cold Forging...Machines, Tools, and Materials Preparation, JSAE, Vol. 73 (1965)

Cold Forging. Wire and Wire Products, (September 1965)

You Can Avoid the High Cost of Heavy Machinery Failures, Met. Progress, Vol. 91 (1967)

The Role of Metallurgy, Particularly Bismuth, Selenium, and Tellerium, in the Machinability of Steels, ASARCO (1968)

Quality Demands-A Challenging Decade Ahead for NDT as Operating and Inspection Tools, Metals/Materials Technology Series, Vol. 8210-068 (1982) 


\section{George F. Vander Voort}

George received his BS in Metallurgical Engineering from Drexel in 1967-the last class as Drexel Institute of Technology. At Drexel he was twice editor-in-chief of the Drexel Technical Journal, including the three years in a row when it was named the number one college technical journal by the Engineering Colleges Magazines Association. He was a member of Blue Key National Honorary Leadership Society and in 1967 he was listed in Who's Who in American Colleges and Universities. Sigma Alpha Mu fraternity named him their outstanding senior in 1967. After graduation, George Joined Bethlehem Steel Corporation in Bethlehem, PA. He received an MS degree in Metallurgy and Materials Science from Lehigh University in 1974 studying under Alan Pense, now Provost of Lehigh University. George worked six years in the metallurgy department of the Bethlehem Plant and was then transferred to their Homer Research Laboratories as a research engineer. Nine years were spent in the Metallurgical Service and Investigations group where George was involved in all areas of microscopy, failure analysis work and alloy development. In 1983, George joined Carpenter Technology Corporation where he is supervisor of Materials Characterization in their research center. He is responsible for all areas of microscopy and mechanical testing.

George has 88 publications, nearly all single authored, including the book Metallography: Principles and Practices (McGraw-Hill, 1984, 752 pgs.). He has edited, or was a co-editor, of thirteen other books and five special issues of Materials Characterization. He is the author of fifteen papers in various editions of the ASM Metals Handbook series and he made eleven of the fourteen video tapes in the ASM video course Principles of Metallography. He is the author of eight ASTM standards and holds five patents. His micrographs have been on the covers of 32 magazines, newsletters, brochures or calendars. He has won 18 awards for his work in metallography contests including the Jacquet-Lucas Grand Prize. He taught physical metallurgy at the Allentown branch of Pennsylvania State University for nine years and a graduate school course on microscopy at Lehigh University. He has taught over thirty one-week courses for ASM's Metals Engineering Institute (including courses for Aramco in Saudi Arabia, Rockwell International, Ford and United Technologies).

George has been active with the International Metallographic Society, IMS, for nearly 20 years, serving on the board of directors, as membership chalrman, secretary, vice president and president (1981-1983). He was general chairman of their 12th annual meeting in 1979. He was series editor of Microstructural Science from 1983 to 1989 and he has chaired three of their symposia. He is associate editor of Materials Characterization (formerly Metallography) published by Elsevier. George received the IMS President's Award in 1987.

George has also been active with the American Society for Testing and Materials, ASTM, where he is a mernber of committees E-4 on Metallography and E-28 on Mechanical Testing. He has been chairman of E.04.14 on Quantitative Metallography since 1982 where he has developed and written standards for both manual and automated quantitative metallographic measurements. He has served, successively, 
as second and first vice-chalrman of E-4 and currently is ending his fourth year as chairman of E-4. He has chalred two international symposia for ASTM E-4. He received the ASTM Award of Merit in 1987 and is a fellow of ASTM. In 1990, he recelved the Anthony DeBellis Memorlal Award from ASTM E-28 for his work on microindentation hardness testing. George is the USA representative to the International Standards Organization, ISO, subcommittee on tests other than chemical and mechanical (SC 7 of TC 17).

George has been active with the American Soclety for Metals (ASM International) since 1966. He was a member of the executive committee of the Lehigh Valley Chapter (secretary, 1971-1974). A past member of the MEI and the Academy Committees, he is currently past chairman and member of the Technical Books Committee and a member and secretary of the Publications Councll. He has been an MEI instructor since 1977 and a member of the Metallography Committee since 1982. He was made a Fellow of ASM in 1990. In 1993, he recelved the Bradley Stoughton Award of the Lehigh Valley Chapter.

George is also a member of TMS of AIME, the International Society for Stereology, and the Royal Microscopical Society (UK). He is married and has two children. When he has some spare time, George enjoys watercolor painting, photography, hiking and camping. 


\section{Distrtbution for NUREG/CR-6183 (ANL-94/3)}

\section{Internal:}

D. R. Diercks (25)

H. Drucker

C. E. Tull

R. W. Weeks

L. A. Nelmark

W. J. Shack

R. B. Poeppel

TIS Fule

\section{External:}

NRC, for distribution per R5

ANL Lubraries

ANL-E (2)

ANL-W

Manager, Chicago Field Office, DOE

Energy Technology Division Review Committee:

H. K. Birnbaum. University of Illinois, Urbana

R. C. Buchanan, University of Cincinnati, Cincinnati

M. S. Dresselhaus, Massachusetts Institute of Technology, Cambridge, MA

B. G. Jones, University of Illinois, Urbana

C.-Y. L, Cornell University, Ithaca, NY

S. N. Lu, Fremont, CA

R. E. Smith, SciTech Inc., Morrisville, NC

D. W. Akers, Idaho National Engineering Laboratory, EG\&G Idaho, Inc., Idaho Falls, ID

S. F. Armour, USDOE, Idaho Field Office, Idaho Falls, ID

Dr. Banaschik, Gesellschaft für Reaktorsicherheit, Zentralstelle

Forschungsbetreuung, Koln 1, Federal Republic of Germany

E. Beckjord, Office of Nuclear Regulatory Research, U.S. Nuclear Regulatory

Commission, Washington, DC

R. W. Bohl. Urbana, IL

J. Bros, TECNATOM S.A., Components Integrity Group, Madrid, Spain

S. Chavez, Idaho National Engineering Laboratory, EG\&G Idaho, Inc., Idaho Falls, ID

S. Chakraborty, Swiss Federal Nuclear Safety Inspectorate, Würenlingen, Switzerland

N. Cole, MPR Assoctates, Washington, DC

F. Corsi, ENEA/VEL-MEP, Rome, Italy

J. Cortez, U.S. Nuclear Regulatory Commission, Washington, DC

P. DeJonghe, Study Centre for Nuclear Energy, SCK/CEN, Bruxelles, Belgium

J. Duco, Department d'Analyse de Süretė, CEN/FAR, Cædex, France

F. Eltawilla, U.S. Nuclear Regulatory Commission, Washington, DC

J. M. Figueras, Consejo de Seguridad Nuclear, Subdireccion de Analysis y Evaluacion. Madrid, Spain

R. G. Gaydos, Rocky River, $\mathrm{OH}$

D. W. Golden, Idaho National Engineering Laboratory, EG\&G Idaho, Inc., Idaho Falls, ID

W. Gomolinskd, IPSN/OSSN, CEN/FAR. Cedex, France

E. M. Hackett, U.S. Nuclear Regulatory Commission, Washington, DC

J. A. Hudson, B388 Harwell Laboratory, UKAEA, Oxfordshire, United Kingdom 
K.H. Katerbau, Staatliche Matertalprüfungsanstalt, Universităt Stuttgart, Stuttgart, Federal Republic of Germany

S. Kawasald, Department of Fuel Safety Research. Japan Atomic Energy Research Institute, Ibarakd-ken, Japan

S. Kinnersly, Technical Area, Severe Accident Analysis, UKAEA, Dorset, United Kingdom

G. Korth. Idaho National Engineering Laboratory, EG\&G Idaho, Inc., Idaho Falls, ID

S. Levin, TMI-2, GPU Nuclear, Middletown, PA

Mr. C. Maricchiolo, ENEA/DISP, Division of Mechanical Analysis \& Technology, Rome, Italy

M. Mayfleld, Office of Nuclear Regulatory Research, Materials Engineering Branch, U.S. Nuclear Regulatory Commisslon, Washington, DC

R. K. McCardell, Idaho National Engineering Laboratory, EG\&G Idaho, Inc., Idaho Falls, ID

D. MCGoff, USDOE, Washington, DC

M. Merilo, EPRI, Palo Aito, CA

P. Milella, ENEA/DISP. Division of Mechanical Analysis \& Technology Rome, Italy

A. G. Miller, Nuclear Safety Division, OECD, Agence pour l'Énergle Nucleaire, Paris, France

R. C. Monroy, Planning Department, Nuclear R\&D Projects, UNIDAD Electrica, S.A. Madrid, Spain

H. Njo, Swiss Federal Nuclear Safety Inspectorate, Würenlingen, Switzerland

C. Ottoson, Finnish Centre for Radiation and Nuclear Safety, Helsinkd, Finland

D. E. Owen, EPRI-TMI-2 Site Office, Middletown, PA

W. F. Pasedag, U.S. Department of Energy, Office of LWR Safety and Technology, Washington, DC

R. Pelli, Technical Research Centre of Finland, Espoo, Finland

G. Petrangell, ENEA/DISP, Sector for Development and Research, Rome, Italy

K. Pettersson, Department of Structural Integrity, Swedish Nuclear Power Inspectorate, Stockholm, Sweden

J. R. Rashid, Anatech Research Corp., San Diego, CA

J. Rempe, Idaho National Engineering Laboratory, EG\&G Idaho, Inc., Idaho Falls, ID

A. M. Rubin, U.S. Nuclear Regulatory Commission, Washington, DC

G. Saponaro, ENEA-DISP, Regulatory Research Commitment, Rome, Italy

H. Schulz, Gesellschaft für Reaktorsicherheit, Zentralstelle Forschungsbetreuung. Koln 1, Federal Republic of Germany

C. Z. Serpan, Office of Nuclear Regulatory Research, Materials Engineering Branch, U.S. Nuclear Regulatory Commission, Washington, DC

L. C. Shao, Division of Engineering, RES, U.S. Nuclear Regulatory Commission, Washington, DC

B. Sheron, U.S. Nuclear Regulatory Commission, Washington, DC

P. Soulat, Service de Recherches Metallurgiciues Appliquees, CEN Saclay, Cedex, France

T. Speis, U.S. Nuclear Regulatory Commission, Washington, DC

K. B. Stadie, OECD, Agence pour l'Énergle Nucleaire, Paris, France

J. Strosnider, U.S. Nuclear Regulatory Commission, Washington, DC

D. Sturm. Staatliche Materialprüfungsanstalt, Universită Stuttgart, Stuttgart, Federal Republic of Germany

G. Thinnes, Idaho National Engineering Laboratory, EG\&G Idaho, Inc., Idaho Falls, ID

M. Trotabas, DMT/SETIC, CEN Saclay, Cedex. France

W. Vandermeulen, Study Centre for Nuclear Energy, SCK/CEN, Bruxelles, Belglum

G. F. Vander Voort, Wyomissing Hills, PA

P. Veron, Equipos Nucleares S.A., Maliano, Cantabria, Spain 
F. Weehuizen, Swiss Federal Nuclear Safety Inspectorate, Würenlingen, Switzerland R. J. Witt, Dept. of Nuclear Engineering, U. of Wisconsin, Madison, WI

J. R. Wolf, Idaho National Engineer'ng Laboratory, EG\&G Idaho, Inc., Idaho Falls, ID 

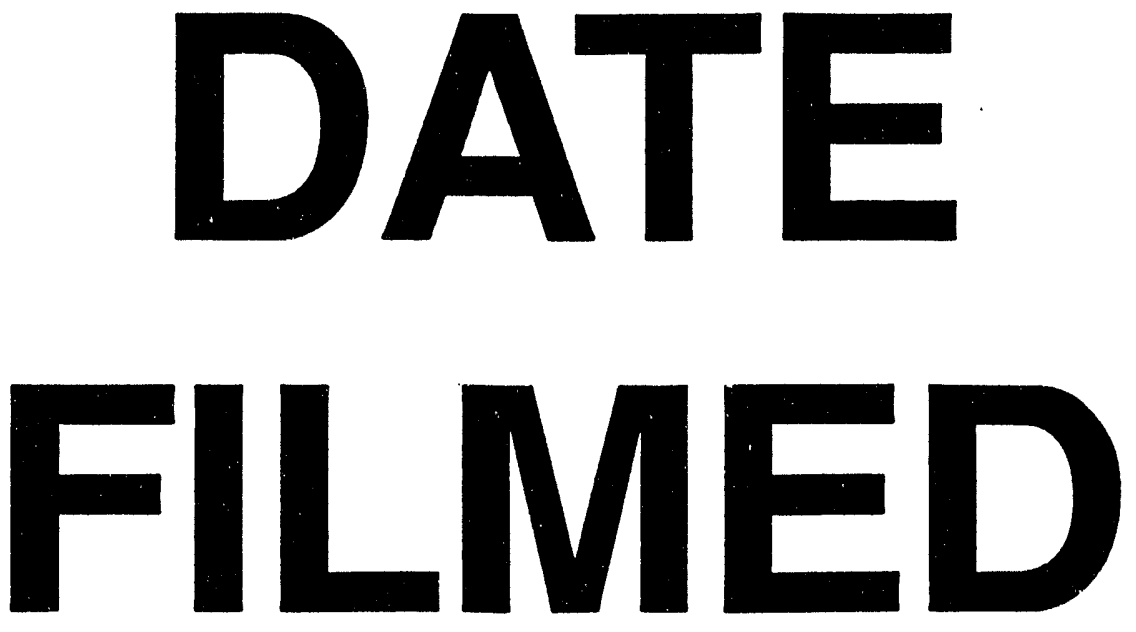

$10 / 25 / 94$
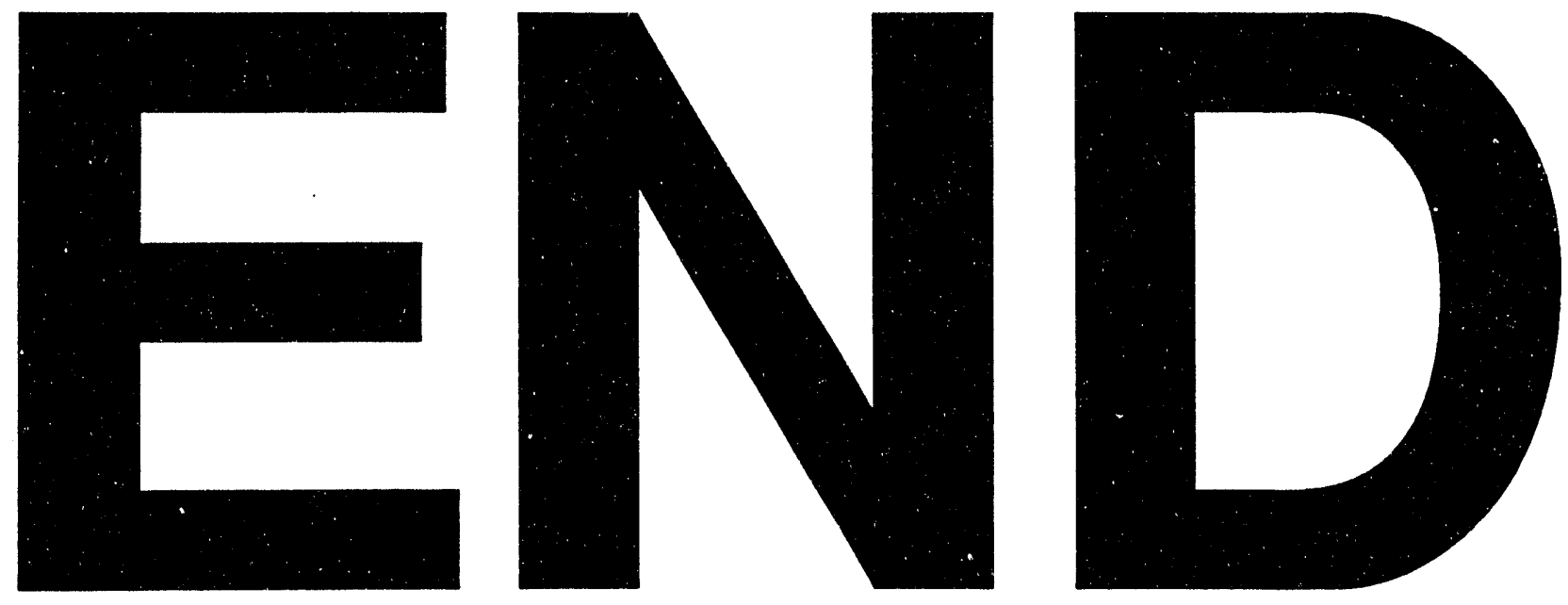
